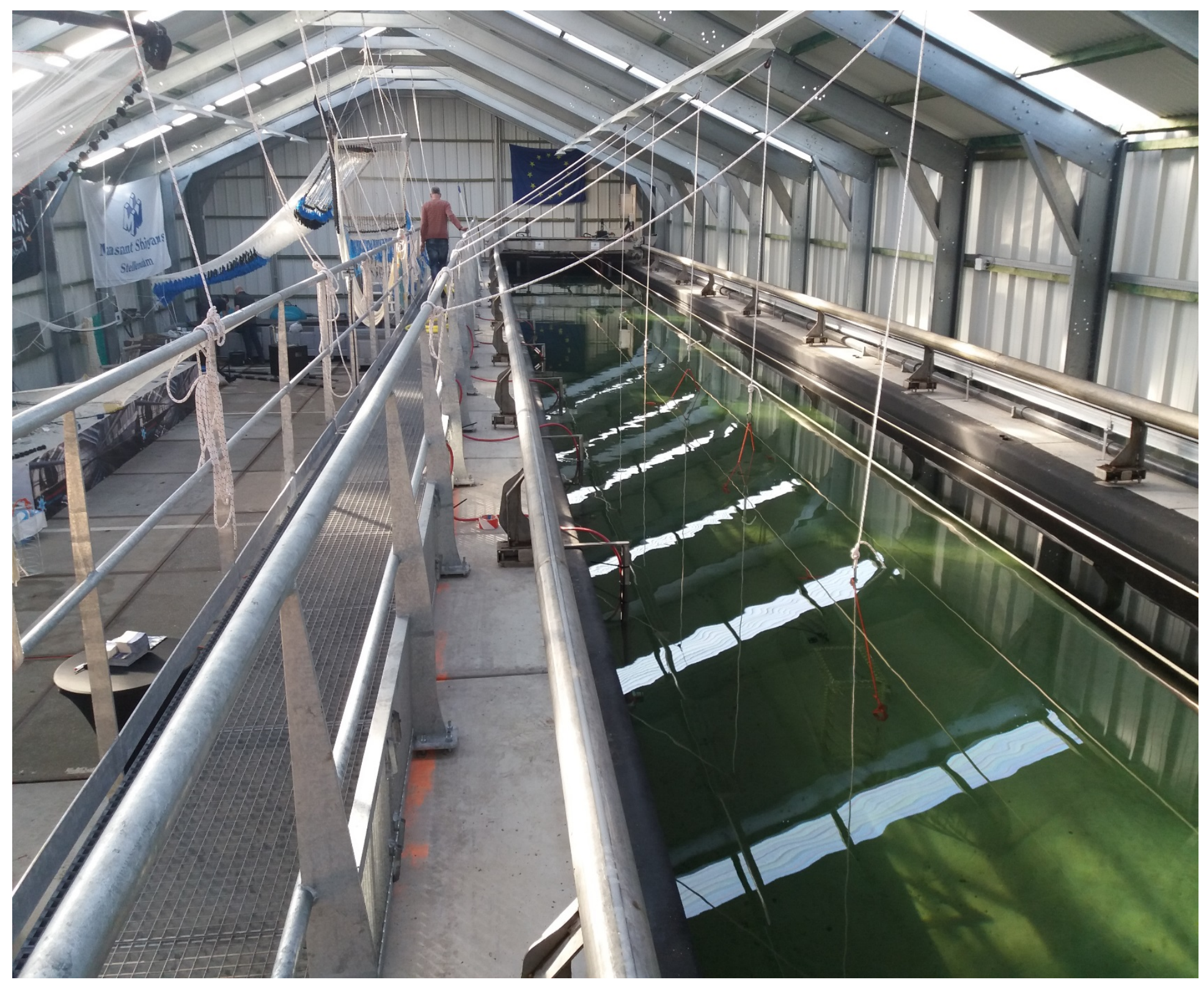

\title{
Selectiviteitsoptimalisatie van de pulsvisserij
}




\section{Selectiviteitsoptimalisatie van de pulsvisserij}

Auteurs:

Opdrachtgever:
Jimmy van Rijn, Pieke Molenaar

Visserij-innovatiecentrum

T.a.v.: dhr J.A. van Nieuwenhuijzen

Meester Snijderweg 7

3251 ๖ Stellendam

Dit project is medemogelijk mogelijk gemaakt door de Stichting

Verduurzaming Visserij Voordelta, Producentenorganisatie Delta Zuid, HFK Engineering en Coöperatie Westvoorn.

Dit rapport is gratis te downloaden van https://doi.org/10.18174/496440

Wageningen Marine Research verstrekt geen gedrukte exemplaren van rapporten.

Wageningen Marine Research is ISO 9001:2015 gecertificeerd. 
van Rijn, J., Molenaar P. 2019. Selectiviteitsoptimalisatie van de pulsvisserij; Wageningen Marine Research, Wageningen Marine Research rapport C072/19, 42 blz.

\section{(C) 2019 Wageningen Marine Research}

Wageningen Marine Research, instituut binnen de rechtspersoon Stichting Wageningen Research, hierbij vertegenwoordigd door Dr. M.C.Th. Scholten, Algemeen directeur

KvK nr. 09098104,

WMR BTW nr. NL 8113.83.696.B16.

Code BIC/SWIFT address: RABONL2U

IBAN code: NL 73 RABO 0373599285
Wageningen Marine Research aanvaardt geen aansprakelijkheid voor gevolgschade, noch voor schade welke voortvloeit uit toepassingen van de resultaten van werkzaamheden of andere gegevens verkregen van Wageningen Marine Research opdrachtgever vrijwaart Wageningen Marine Research van aanspraken van derden in verband met deze toepassing. Alle rechten voorbehouden. Niets uit deze uitgave mag weergegeven en/of gepubliceerd worden, gefotokopieerd of op enige andere manier gebruikt worden zonder schriftelijke toestemming van de uitgever of auteur. 


\section{Inhoud}

$\begin{array}{lr}\text { Samenvatting } & 4\end{array}$

$\begin{array}{ll}\text { Summary } & 5\end{array}$

$1 \quad$ Inleiding $\quad 6$

2 Kennisvraag $\quad 7$

3 Methoden $\quad 8$

$\begin{array}{llr}3.1 & \text { Ethische gronden } & 8\end{array}$

3.2 Proefopzet $\quad 8$

3.2.1 Bassin en loopwagen 9

3.2.2 Kooien 9

$\begin{array}{ll}3.2 .3 \text { Pulselektroden } & 10\end{array}$

$\begin{array}{lll}3.2 .4 & \text { Camera's } & 10\end{array}$

$\begin{array}{ll}3.3 \text { Proefdieren } & 11\end{array}$

$\begin{array}{ll}3.4 & \text { Experimenten }\end{array}$

$\begin{array}{ll}3.5 & \text { Analyse video observaties } \\ \end{array}$

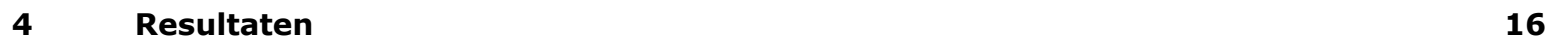

4.1 Tong 16

$\begin{array}{lll}4.1 .1 & \text { Spanning } & 16\end{array}$

$\begin{array}{lll}4.1 .2 & \text { Frequentie } & 17\end{array}$

$\begin{array}{lll}4.1 .3 & \text { Pulsduur } & 18\end{array}$

$\begin{array}{ll}4.2 \text { Schol } & 19\end{array}$

$\begin{array}{lll}4.2 .1 & \text { Spanning } & 19\end{array}$

$\begin{array}{lll}4.2 .2 & \text { Frequentie } & 20\end{array}$

$\begin{array}{lll}4.2 .3 & \text { Pulsduur } & 21\end{array}$

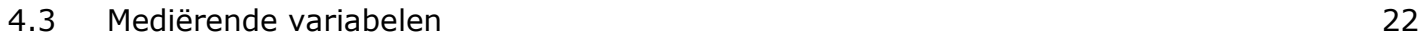

4.3.1 Conditioneringsexperiment $\quad 22$

4.3.2 Mate van ingraven 23

$\begin{array}{lll}4.3 .3 & \text { Oriëntatie } & 24\end{array}$

5 Discussie $\quad 25$

6 Conclusies $r 2$

$\begin{array}{llr}7 & \text { Kwaliteitsborging } & 27\end{array}$

$\begin{array}{lr}\text { Literatuur } & 28\end{array}$

$\begin{array}{lr}\text { Verantwoording } & 29\end{array}$

$\begin{array}{llr}\text { Bijlage } 1 & \text { Grafieken } & 30\end{array}$

$\begin{array}{lll}\text { Bijlage } 2 & \text { Video analyse protocol } & 31\end{array}$

Bijlage $3 \quad$ Voorwaarden toestemming pulsvisserij (RvO) 36 


\section{Samenvatting}

Onderzocht is of het selectieve karakter van de pulsvisserij verder versterkt kan worden door de optimalisatie van pulsinstellingen. In het kader van de aanlandplicht is het wenselijk om de vangkans van ondermaatse schol en tong terug te dringen zonder ten koste te gaan van de marktwaardige vangst. Om het selectieve effect van verschillendede pulsinstellingen (binnen de wettelijke bandbreedte) te testen zijn in mei 2018, verdeeld over drie dagen, in het Visserij-innovatiecentrum in Stellendam, 11 proeven uitgevoerd met tong en schol. Tijdens de proeven werd enkel één instelling veranderd en zijn de andere twee op de commerciële instelling gezet; 60 hertz - $350 \mu s-60$ volt. Om het selectieve effect te bestuderen is er geëxperimenteerd met oplopende niveaus van spanning (volt), frequentie (hertz) en pulsduur ( $\mu s)$.

In het 32,8 meter lange zeewater bassin stonden vijf kooien met vissen in een rij achter elkaar. Voor elke proef zijn de vissen per soort en lengteklasse gegroepeerd en in een kooi geplaatst. Per instelling zijn drie oplopende variaties in de instelling in achtereenvolgende proeven getest met dezelfde groep vissen, waarbij een rustperiode van 60 minuten tussen de herhalingen werd aangehouden. Tijdens de proef werden de pulselektroden met een snelheid van 4 mijl per uur langs de kooien gesleept. De reacties van de vis zijn met een camera van de zijkant en bovenkant opgenomen. De videobeelden zijn geanalyseerd op de intensiteit van de reacties (bv. geen, trillen, vluchten, etc.) tijdens en na de blootstelling aan de puls-prikkeling.

Het effect van de mediërende variabelen op de resultaten is moeilijk te duiden en daarom is er gekeken naar de meest duidelijke effecten van de pulsinstellingen op de reactie van de vissen. Tijdens alle experimenten was het duidelijk dat tong intenser reageert op de puls-prikkeling dan schol. Verder lieten de experimenten zien dat het mogelijk was om selectief de intensiteit waarmee verschillende lengteklassen van tong reageerden, te sturen. De reactie van schol daarentegen liet geen duidelijk onderscheid zien tussen de verschillende lengteklassen. De puls-prikkeling heeft bij schol een minder duidelijk effect. Een toename in spanning (volt) versterkte de reactie van kleine tong en alle maten schol. Naarmate een hogere frequentie (hertz) toegepast werd, was de reactie van tong sterker. Dit effect was bij schol minder eenduidig. Pulsduur had het meest selectieve effect, vooral bij grotere tongen werd een intensere reactie waargenomen en waarbij er geen duidelijk effect zichtbaar was bij de overige lengteklassen en schol. Uit deze experimenten lijkt het mogelijk om met een combinatie tussen de optimale pulsduur, frequentie en spanning de selectiviteit van het pulstuig te optimaliseren zodat de vangst van marktwaardige vis behouden blijft, maar de vangst van kleine (ondermaatse) schol en tong beperkt wordt. Vervolgonderzoek zou zich moeten focussen op een groter aantal herhalingen van de proeven om ervoor te zorgen dat het effect van de pulsinstelling op de vis door de puls-prikkeling beter te onderscheiden is van het effect door de mediërende factoren (oriëntatie en mate van ingraven). 


\section{Summary}

It has been investigated whether the selective nature of pulse fishing can be further enhanced by the optimization of pulse settings. In the context of the landing obligation, it is desirable to reduce the chance of catching undersized plaice and sole without affecting the marketable catch. To test the selective effect of different pulse settings (within the legal bandwidth), in May 2018, divided over three days, in the Fisheries Innovation Center in Stellendam, 11 tests were carried out with sole and plaice. During the tests, only one setting was changed and the other two were placed on the commercial setting; 60 hertz - $350 \mu s-60$ volts. To study the selective effect, experiments were carried out with increasing levels of voltage (volts), frequency (hertz) and pulse duration ( $\mu s)$.

In the 32.8 meter long seawater basin five cages with fish stood in a row behind each other. For each test, the fish are grouped by species and length class and placed in a cage. For each setting, three increasing variations in the setting were tested in successive tests. This was done with the same group of fish and with a 60-minute rest period between repetitions. During the test, the pulse electrodes were dragged over the bottom along the cages at a speed of 4 miles per hour. The reactions of the fish were recorded with a camera from the side and top perspective. The videos were analysed for the intensity of the responses (e.g. none, vibrations, flights, etc.) during and after exposure to the pulse stimulation.

The effect of the mediating variables on the results is difficult to explain and therefore only the most obvious effects of the pulse settings on the reaction of the fish are discussed. During all experiments it was clear that sole reacts more intensively to pulse stimulation than plaice. Furthermore, the experiments showed that it was possible to selectively control the intensity with which different length classes of sole responded. Responses by plaice did not show a clear distinction between the different length classes. In general the pulse stimulation has a less clear effect on plaice. An increase in voltage (volts) amplified the response of small sole and all sizes of plaice. As a higher frequency (hertz) was applied, the response of sole got stronger. This effect was less clear in plaice. Pulse duration had the most selective effect, in particular on larger sole specimens, a more intense response was observed and with no clear effect visible in the other length classes and plaice specimens. From these experiments it seems possible to optimize the selectivity of the pulse gear with a combination of the optimal pulse duration, frequency and voltage, so that the catch of marketable fish is retained, but the catch of small (undersized) plaice and sole is limited. Follow-up research should focus on a greater number of repetitions of the tests to ensure that the effect of the pulse setting on the fish by the pulse stimulation can be better distinguished from the effect by the mediating factors (orientation and degree of burrowing). 


\section{$1 \quad$ Inleiding}

Binnen de context van het Gemeenschappelijke Visserijbeleid (GVB) en de aanlandplicht wordt de visserij gestimuleerd om ongewenste bijvangst te reduceren. Waar voorheen een aanlandquotum werd gehanteerd heeft nu een gefaseerde overgang plaatsgevonden naar een vangstquotum. Voor gequoteerde soorten betekent dit dat er geen teruggooi van ondermaatse exemplaren ('discarding') meer mag plaatsvinden en dat het soort specifieke quotum geldt voor zowel maatse als ondermaatse vis. Alle gevangen vissen onder een vangstquotum moeten aangeland worden onder de aanlandplicht (EU, 2013; $E U, 2015)$. Om duurzamer en efficiënter gebruik te maken van het vangstquotum onder de aanlichtplicht is een selectievere visserij gewenst, waarbij de vangst van ondermaatse vis zoveel mogelijk vermeden wordt.

Waar voorheen de Nederlandse platvis visserij enkel plaatsvond met de traditionele boomkor bestaan er nu meerdere alternatieve methodes, waar de pulskor er één van is. De pulskor is ook een vistuig dat over de zeebodem sleept, alleen wordt de vis geprikkeld om de zeebodem te verlaten met elektrische pulsen als alternatief voor de zware kettingen die gebruikt worden in de traditionele boomkorvisserij. De prikkeling wordt afgegeven door elektroden die van de boom of wing naar de onderpees van het net lopen waarbij de elektroden over de bodem slepen en de elektrische pulsen afgeven. Van deze electoden is de laatste 4 meter uitgerust met isolatoren en een reeks conductoren welke een snelheid van 4.5-5.0 mijl per uur worden voortgetrokken, hiermee worden vissen en organismen op de zeebodem maximaal 1.5 tot 2 seconde aan de elektrische pulsen blootgesteld (De Haan et al. 2016). Deze elektrische pulsen veroorzaken een korte spierverkramping, hierdoor buigen de ingegraven platvissen geïmmobiliseerd in een U-vorm waardoor ze grotendeels of volledig los komen van de zeebodem. Omdat de vissen los zijn van de zeebodem zorgt de grondpees van het net er voor dat ze over de pees heen in het net komen en gevangen worden.

In theorie bestaat er met de puls methode nog ruimte om de selectiviteit te verhogen door de pulsinstellingen zodanig af te stellen dat de vangkans voor ondermaatse vis verkleind wordt zonder verlies van marktwaardige vis. In dit onderzoek wordt er onder gecontroleerde omstandigheden naar de optimalisatie van de selectiviteit van de puls instellingen gekeken.

In deze studie is onderzocht hoe tong en schol van verschillende lengteklassen reageren op de elektrische prikkels van een voortgesleepte pulsmodule, waarbij de instellingen stapsgewijs aangepast worden. De experimenten zijn uitgevoerd in de sleeptank van het Visserij-innovatiecentrum Zuidwest Nederland (VIC) in Stellendam. De pulsinstellingen waarmee geëxperimenteerd is zijn frequentie (hertz), spanning (volt) en pulsduur (microseconde). Tijdens deze experimenten is de reactie van vissen op deze drie pulsinstellingen (binnen de wettelijke bandbreedte zoals beschreven in bijlage 3, hierna: 'range') geregistreerd met camera's en zijn hun reacties aan de hand van de videobeelden geanalyseerd. Deze experimenten hebben plaatsgevonden onder begeleiding van een onderzoeker met de artikel 9 bevoegdheid om dierproeven uit te voeren. 


\section{Kennisvraag}

Het doel van deze proef is om te onderzoeken met welke combinatie van pulsinstellingen de marktwaardige vissen reageren op de puls-prikkels terwijl ondermaatse exemplaren niet reageren. In deze rapportage wordt verslag gedaan van de resultaten van de selectiviteitsexperimenten met schol en tong. 


\section{Methoden}

Het hoofdstuk begint met een notitie over de ethische gronden van de uitgevoerde studie. De manier waarop de proef is opgezet wordt daarna uitgelegd in het algemeen. Na de algemene beschrijving worden vier belangrijke praktische elementen van de proefopzet toegelicht (bv kooien en camera's). Daarna wordt de wijze waarop de proefdieren zijn verkregen, gehuisvest en voorbereid op het onderzoek uitgelegd. Hierop volgt een overzicht van de experimenten en de reden waarom deze als beschreven plaatsgevonden hebben. De wijze waarop de reacties van de vissen geanalyseerd is wordt uitgelegd in het laatste subhoofdstuk.

\subsection{Ethische gronden}

De dierproeven voor deze studie zijn in overeenkomst met de Nederlandse Wet op de Dierproeven uitgevoerd. Het experiment is beoordeeld door de Dierexperimentencomissie en goedgekeurd door de Centrale Commissie Dierproeven (Experiment 2017.D-0012.003).

\subsection{Proefopzet}

Pulsfrequentie (hertz), pulsspanning (volt) en pulsbreedte (microseconde) zijn de drie geteste variabelen in deze proeven. Voor elke variabele is wettelijk vastgelegd binnen welke range deze ingesteld moet zijn. In deze studie wordt het effect van elke variabele afzonderlijk onderzocht. Uitgaande van een basisinstelling, 60 hertz - $350 \mu$ s - 60 volt, wordt per testdag het effect op schol en tong van één van de instellingen op drie niveaus getest. De overige twee variabelen worden ingesteld op de basisinstelling. Op deze manier worden dus achtereenvolgens de pulsfrequentie, pulsspanning en pulsbreedte elk op 3 niveaus getest. Elk experiment leidt naar verwachting tot een optimaal instellingsniveau voor de betreffende variabele.

Tijdens een testdag worden de vissen blootgesteld aan de puls-prikkeling door de deze in kooien in de testopstelling (bassin met zeewater) te plaatsen en de elektroden er langs te slepen op commerciële snelheid (Figuur 1). De reactie van de vissen op de puls-prikkeling wordt vastgelegd met onderwatercamera's waarbij er van boven en van de zijkant opnamen gemaakt en opgeslagen worden voor analyse. De opnames worden gebruikt om vast te stellen hoeveel van de vissen in een kooi reageren bij blootstelling aan de puls-prikkel. Hierbij wordt gekeken naar de intensiteit van de reactie tijdens de blootstelling (geen, schudden, verkramping) en direct na blootstelling (geen, ingraven, wegzwemmen).

De vissen worden achtereenvolgens aan de drie oplopende niveaus van de te testen pulsinstelling blootgesteld. Tussen elke blootstelling zit een rustperiode van 1 uur. Doordat gewerkt wordt in een lang bassin kunnen meerdere kooien achter elkaar geplaatst worden en daardoor meerdere groepen vissen (verschillende lengteklassen en/of vissoorten) gelijktijdig getest worden.

Om vast te stellen dat de reactie van de vissen op de puls niet veranderd als gevolg van herhaalde blootstelling, is de eerste groep vissen de eerste dag driemaal blootgesteld aan dezelfde instellingen. Daarna is gekeken of de vissen gewenning vertoonde door alreeds te reageren bij het geluid van de sleep installatie en het passeren van de elektrode zonder prikkeling 
Om het effect van pulsinstellingen op verschillende visgroottes vast te kunnen stellen is gewerkt met lengteklassen. Schol en tong zijn onderverdeeld in 4 lengteklassen van vijf centimeter, beginnend vanaf $15-20 \mathrm{~cm}$ tot $35+\mathrm{cm}$. Deze lengteklassen dekken de voornaamste range tussen ondermaatse en maatse vis. Van elke klasse zijn 5 individuen gebruikt om inzicht te krijgen in de specifieke variatie binnen een groep. Het is noodzakelijk om meerdere individuen per groep te testen omdat in theorie de oriëntatie (ligging) en lengte van de vis invloed hebben op de intensiteit van de blootstelling. Een vis die parallel ligt aan de elektrode zou een minder intense prikkel moeten ervaren dan een vis die haaks op de richting van de elektrode ligt doordat er op deze manier een groter potentiaalverschil ontstaat.
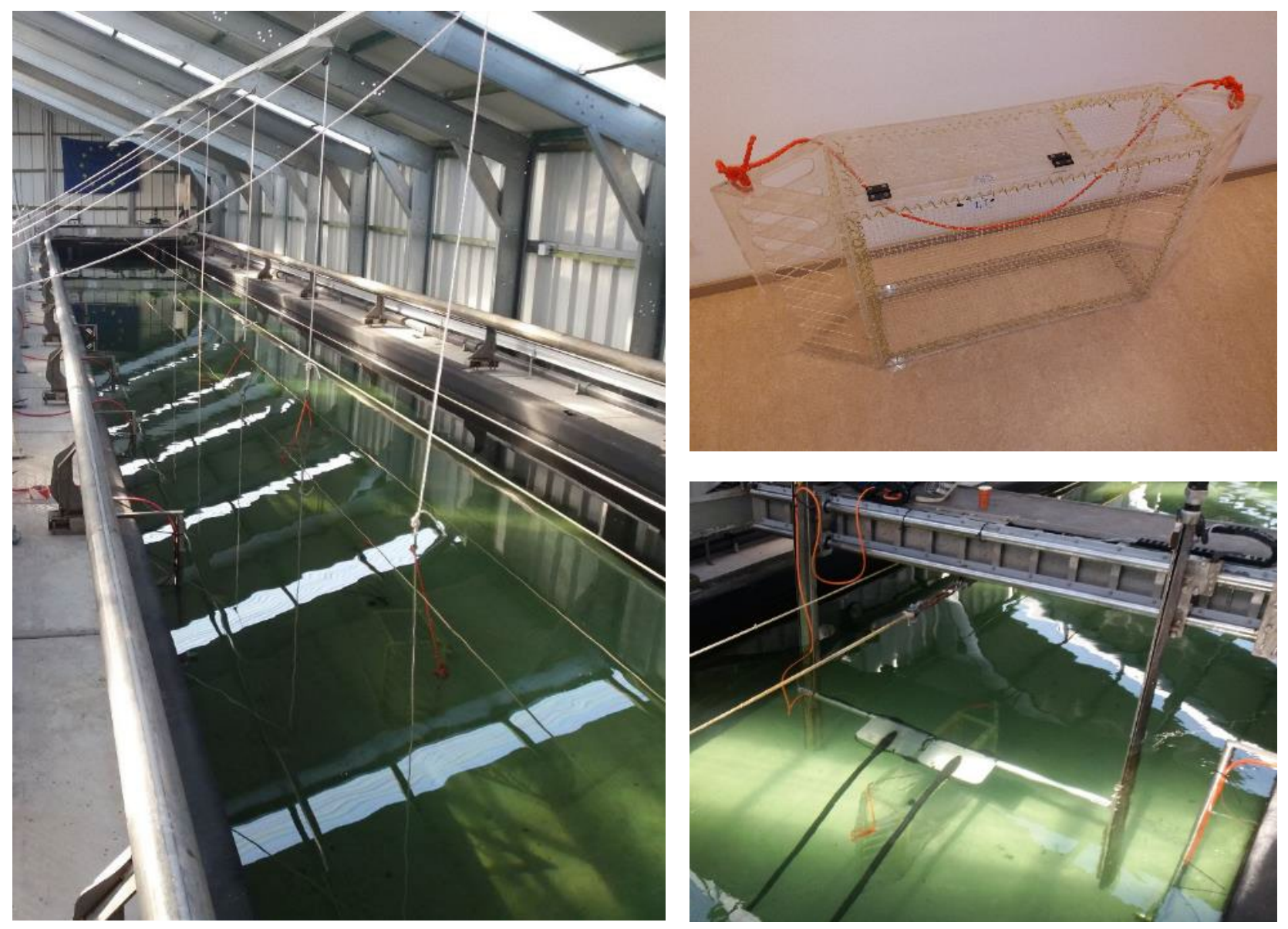

Figuur 1 De test bassin (links) in het VIC met de rails voor de wagen en de kooien in het water. De kooi (rechtsboven) wordt gebruikt om de vissen tussen de puls-elektroden te houden. Het netwerk is bevestigd in het rechthoekige plexiglas frame van de kooi. De loopwagen (rechtsonder) met daaronder de puls-elektrodes bevestigd, de elektrode zijn zo gepositioneerd dat ze precies langs beide zijden van de kooien gaan.

\subsubsection{Bassin en loopwagen}

In het VIC staat een bassin van 32,8×3,2x2 meter ( $\mathrm{LxBxH}$ ) gevuld met 175 kuub zeewater. Boven het bassin is een rails bevestigd waar een loopwagen overheen kan bewegen met snelheden tot 4,5 mijl per uur. De pulselektroden zijn bevestigd aan de loopwagen en worden hiermee door het bassin en langs de kooien gesleept.

\subsubsection{Kooien}

Voor deze proef is er gebruik gemaakt van speciaal ontworpen kooien van $151 \times 30 \times 70$ centimeter (LxBxH) door 'Van Wijk installaties \& Constructies'. Deze kooien bestaan uit een frame van plexiglas en fijnmazig $(20 \mathrm{~mm}$ ) nylon netwerk tussen de framedelen (Figuur 1) die vrije uitwisseling van water en elektriciteit mogelijk maken maar vissen binnen de kooi houden. De kooien zijn ongeveer 4 centimeter in de zandbodem van de bak ingegraven met behulp van een waterpomp en in een rij 
achter elkaar geplaatst (Figuur 1). Het ingraven van de kooien zorgt ervoor dat de vissen zich op een natuurlijk manier kunnen ingraven en dat de kooien stabiel blijven staan na het passeren van de loopwagen en elektroden.

\subsubsection{Pulselektroden}

De twee puls-elektrodes zijn bevestigd op de loopwagen met daartussen een afstand van $42 \mathrm{~cm}$, vergelijkbaar met de afstand tussen de elektrodes op een boom of wing in een commerciële situatie. De puls-elektrodes hingen met een boogje naar de zandbodem (Figuur 1 ) en hebben een totale lengte van 7 meter waarvan alleen het uiteinde van 4,4 meter is voorzien van conductoren die de pulsprikkeling veroorzaken (Figuur 2). De conductoren zijn in een serie van drie achter elkaar geplaatst met tussen elke conductor een $13,75 \mathrm{~cm}$ lange isolator. Elke electrode heeft vier groepen met conductoren met daartussen een aaneengesloten isolator van 60 centimeter tussen de groepen die geen prikkeling afgeeft.

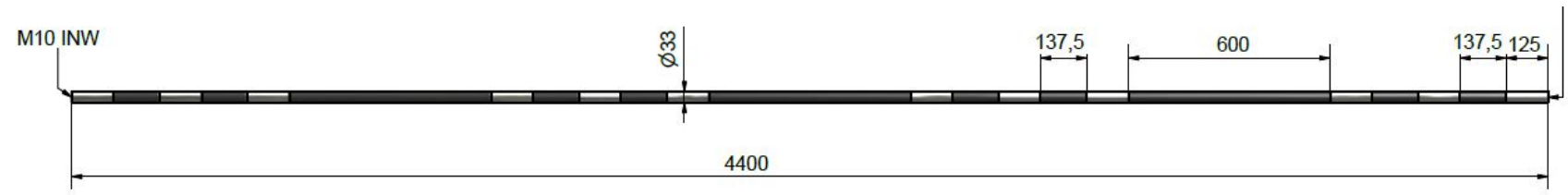

Figuur 2 Uiteinde van de puls-elektrode is 4,4 meter lang en de lichte delen op de kabel zijn de conductoren $(12,5 \mathrm{~cm})$ die pulserende stroom afgeven.

\subsubsection{Camera's}

In de deksel van elke kooi is een GoPro camera bevestigd voor het bovenaanzicht tijdens de proeven (Figuur 3). Tevens is er aan de zijkant van elke kooi een camera geplaatst die een beeld geeft van wat er zich boven de bodem afspeelt. Om tijdens de video analyse het proef- en kooinummer te kunnen achterhalen zijn in het netwerk van de viskooi watervaste kaartjes met proefnummers bevestigd. Deze kenmerken zijn op beide camera's zichtbaar.

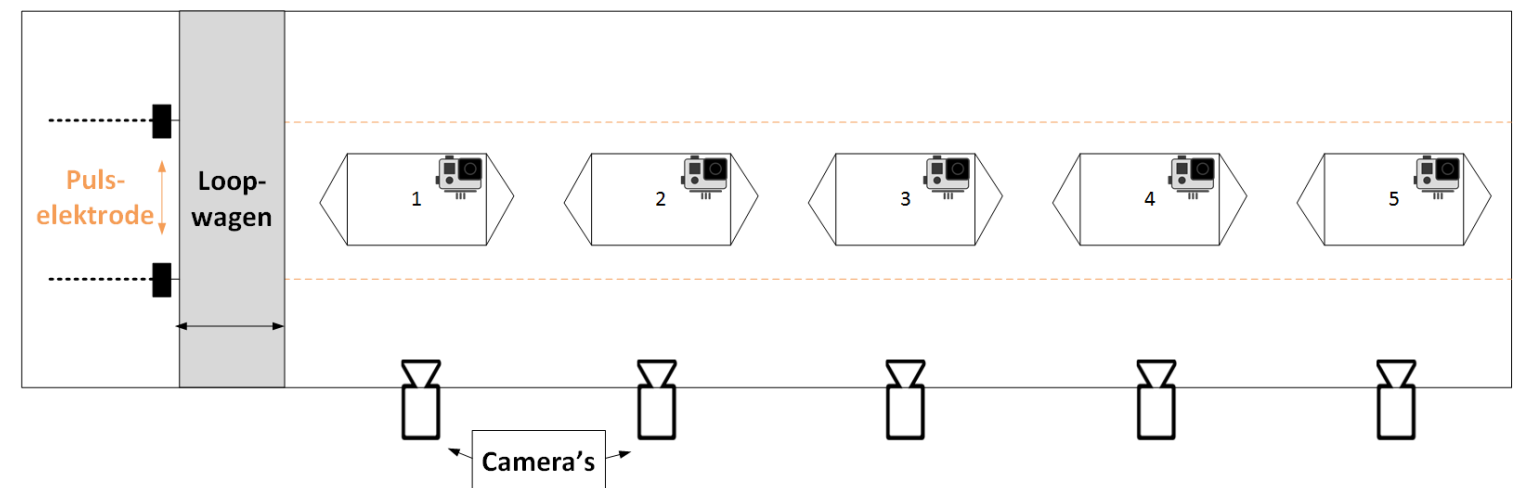

Figuur 3 In het zoutwaterbassin in het VIC zijn vijf viskooien in een rij geplaatst zodat de loopwagen met de puls-elektroden dicht langs de kooi kon slepen. De reactie op deze prikkeling is geregistreerd met een GoPro camera die bevestigd was in de deksel van elke kooi en met camera's vanaf de zijkant. In de schematische tekening van de bak zie je links de loopwagen, met de puls-elektrode (zwarte stippellijn). De loopwagen beweegt over een geleiderail boven het water waarbij de puls elektroden precies langs de kooien met vis slepen.

In de ochtend zijn de vissen door de dierverzorger en bevoegd onderzoeker van de opslagtubs overgebracht naar de kooi in het bassin. Na de acclimatisatieperiode zijn de GoPro camera's handmatig gestart door een duiker en kort daarop heeft de eerste proef plaatsgevonden. Na afloop van de proef is de loopwagen terug naar het begin van het bassin gereden en heeft de duiker de GoPro's uitgezet. Tegelijkertijd zijn de vissen geïnspecteerd. Na drie proeven met dezelfde vissen zijn deze beoordeeld door de bevoegd onderzoeker en levend vrijgelaten in hun natuurlijke habitat. Voor het volgende experiment zijn nieuwe vissen in de kooien geplaatst en na een acclimatisatieperiode herhaalde de bovenstaande procedure zich. 


\subsection{Proefdieren}

De tongen en schollen zijn vooraf gevangen door een commerciële kotter. Om de vissen in zo goed mogelijke conditie aan boord en in het VIC te krijgen werden de vissen gevangen met korte trekken. Aan boord zijn de vissen met de beste conditie en minste beschadigingen uit de vangst geselecteerd. De vissers waren hierin getraind omdat zij voor Experiment 2017D.0012.002 op vergelijkbare wijze vissen verzameld hebben. Aan boord worden de vissen in beluchte en doorstroomde 600L tubs gehouden. Bij terugkomst in de haven worden de tubs overgebracht naar het VIC in Stellendam en gehuisvest in speciale tubs voorzien van beluchting en doorstromend van water uit het grote bassin. De bodem is bedekt met grof zand en de vissen worden gevoerd met zagers en ongekookte garnalen. De vissen verblijven hier meerdere dagen om te herstellen zodat ze in goede conditie zijn op het moment dat ze bij de proef worden ingezet. Dit moet ervoor zorgen dat de vissen 'normaal gedrag' vertonen bij de proeven. 


\subsection{Experimenten}

Om het effect van pulsinstellingen op vislengte vast te kunnen stellen is gewerkt met lengteklassen. Schol en tong zijn onderverdeeld in 4 lengte klassen. Van elke klasse worden 5 individuen ingezet om inzicht te krijgen in de verschillen in reactie binnen een groep. In theorie bepaalt de oriëntatie ten opzichte van de elektrode en de lengte van de vis hoe intens deze aan de puls-prikkeling blootgesteld wordt. Aangezien de oriëntatie van de vissen in de kooien niet te beïnvloeden is, krijg je een willekeur aan oriëntaties per proef. Om dit reden is het noodzakelijk om per groep meerdere individuen te testen en een gemiddeld beeld te krijgen van de reactie per pulsinstelling.

Verdeeld over drie testdagen hebben 11 proeven plaatsgevonden. De eerste test dag is gebruikt om vast te stellen of de vissen conditionering of gewenning vertonen aan de puls-prikkeling door bij herhaalde prikkeling meer of minder intens te reageren. Tevens is er gekeken of de vissen al een reactie tonen wanneer ze het geluid van de loopwagen horen of wanneer de elektroden langs komen zonder dat de elektriciteit aan staat. Na de evaluatie van het gewenningsexperiment is op de volgende dag het effect van spanning (volt) en frequentie (hertz) getest. Twee weken later is het effect van pulsduur $(\mu \mathrm{s})$ getest. Een overzicht van de experimenten is gegeven in Tabel 1.

Tabel 1 Overzicht van de uitgevoerde experimenten. De grijze blokken geven de pulsinstellingen weer waar mee getest en gevarieerd is.

\begin{tabular}{|c|c|c|c|c|c|c|c|c|}
\hline \multirow[t]{2}{*}{ trek nr. } & \multirow[t]{2}{*}{ Datum } & \multirow[t]{2}{*}{ Tijd } & \multicolumn{3}{|c|}{ Pulsinstelling } & \multirow{2}{*}{$\begin{array}{c}\text { Saliniteit } \\
\mathrm{g} / \mathrm{L}\end{array}$} & \multirow{2}{*}{$\begin{array}{c}\text { Water temp } \\
\text { Celsius }\end{array}$} & \multirow[t]{2}{*}{ Type experiment } \\
\hline & & & Hertz & $\mu s$ & Volt & & & \\
\hline 2 & 15-mei-19 & $13: 14$ & 60 & 350 & 58 & 20 & 17.6 & Conditionering \\
\hline 3 & 15-mei-19 & $14: 24$ & 60 & 350 & 58 & 20 & 17.6 & Conditionering \\
\hline 6 & 15-mei-19 & $16: 26$ & 60 & 350 & 58 & 20 & 17.6 & Conditionering \\
\hline 1 & 16-mei-19 & $10: 21$ & 60 & 350 & 45 & 20 & $N A$ & Spanning \\
\hline 2 & 16-mei-19 & $11: 21$ & 60 & 350 & 60 & 20 & $N A$ & Spanning \\
\hline 3 & 16-mei-19 & $13: 08$ & 85 & 350 & 60 & 20 & $N A$ & Frequentie \\
\hline 4 & 16-mei-19 & $14: 10$ & 30 & 350 & 60 & 20 & $N A$ & Frequentie \\
\hline 5 & 16-mei-19 & $15: 10$ & 60 & 350 & 60 & 20 & $N A$ & Frequentie \\
\hline 1 & 28-mei-19 & $12: 52$ & 60 & 150 & 60 & 20 & 19.7 & Pulsduur \\
\hline 2 & 28-mei-19 & $13: 52$ & 60 & 250 & 60 & 20 & 19.7 & Pulsduur \\
\hline 3 & 28-mei-19 & $14: 52$ & 60 & 400 & 60 & 20 & 19.7 & Pulsduur \\
\hline
\end{tabular}

Het aanbod van vissen was te beperkt om voor elke proef dezelfde lengteklassen te gebruiken en daarom zijn in sommige proeven wisselende lengteklassen gebruikt (Tabel 2). Bij de laatste drie proeven op 16 mei waren er geen tongen meer in de $30-35 \mathrm{~cm}$ lengteklasse en is in de plaats hiervan vissen van een grotere lengteklasse (35+) gebruikt. Op 28 mei waren er geen schollen van de 25-30 $\mathrm{cm}$ lengteklasse en zijn er vijf exemplaren van de $30-35 \mathrm{~cm}$ klasse ingezet. Er is voor gekozen om altijd twee kooien te vullen met schol en drie kooien met tong om zo de effecten op beide soorten waar te nemen. Bij elke proef zaten er in iedere kooi vijf vissen. Het overzicht van de vissen die gebruikt zijn bij de experimenten is weergegeven in Tabel 2. 
Tabel 2 Overzicht van het aantal vissen per lengteklasse gebruikt in de experimenten

\begin{tabular}{|c|c|c|c|c|c|c|c|c|c|c|c|}
\hline \multirow[t]{2}{*}{ trek nr. } & \multirow[t]{2}{*}{ Datum } & \multirow[t]{2}{*}{ Tijd } & \multicolumn{5}{|c|}{ Tong } & \multicolumn{4}{|c|}{ Schol } \\
\hline & & & $15-20$ & $25-30$ & $30-35$ & $35+$ & Totaal & $15-20$ & $25-30$ & $30-35$ & Totaal \\
\hline 2 & 15-mei-19 & $13: 14$ & 5 & 5 & 5 & 0 & 15 & 5 & 5 & 0 & 10 \\
\hline 3 & 15-mei-19 & $14: 24$ & 5 & 5 & 5 & 0 & 15 & 5 & 5 & 0 & 10 \\
\hline 6 & 15-mei-19 & $16: 26$ & 5 & 5 & 5 & 0 & 15 & 5 & 5 & 0 & 10 \\
\hline 1 & 16-mei-19 & $10: 21$ & 5 & 5 & 5 & 0 & 15 & 5 & 5 & 0 & 10 \\
\hline 2 & 16-mei-19 & $11: 21$ & 5 & 5 & 5 & 0 & 15 & 5 & 5 & 0 & 10 \\
\hline 3 & 16-mei-19 & 13:08 & 5 & 5 & 0 & 5 & 15 & 5 & 5 & 0 & 10 \\
\hline 4 & 16-mei-19 & $14: 10$ & 5 & 5 & 0 & 5 & 15 & 5 & 5 & 0 & 10 \\
\hline 5 & 16-mei-19 & $15: 10$ & 5 & 5 & 0 & 5 & 15 & 5 & 5 & 0 & 10 \\
\hline 1 & 28-mei-19 & $12: 52$ & 5 & 5 & 5 & 0 & 15 & 5 & 0 & 5 & 10 \\
\hline 2 & 28-mei-19 & $13: 52$ & 5 & 5 & 5 & 0 & 15 & 5 & 0 & 5 & 10 \\
\hline 3 & 28-mei-19 & $14: 52$ & 5 & 5 & 5 & 0 & 15 & 5 & 0 & 5 & 10 \\
\hline
\end{tabular}




\subsection{Analyse video observaties}

Per experiment zijn de volgende algemene gegevens geregistreerd; proefnummer, datum, tijd, saliniteit, watertemperatuur, pulsspanning, pulsfrequentie, pulsduur, treksnelheid, kooi nummer, vissoort, lengteklasse vis, aantal blootstellingen en aantal individuen per kooi.

De rest van de gegevens die geregistreerd zijn, bestaan uit observaties uit de videoanalyse die inzicht geven tot de reactie van vissen op en na de puls-prikkeling. Voor de video analyse kregen de vissen per kooi eerst een identificatienummer toegewezen om hun reacties tijdens de proeven te kunnen relateren aan hun oriëntatie en mate van ingraven. Daarna werd voor elke vis genoteerd wat hun oriëntatie was en in welke mate ze ingegraven waren. De reacties van de vissen tijdens de blootstelling zijn geclassificeerd in een oplopende mate van intensiteit. Omdat de reacties na blootstelling geen duidelijk patroon van intensiteit lieten zien is er gekozen om alle waargenomen reacties te noteren. Tevens is het hoogste punt boven de zandbodem bijgehouden per vis.

Met deze gegevens is een inschatting gemaakt van in welke mate de vissen reageren op de pulsprikkeling en of oriëntatie en mate van ingraven hier ook een effect op hebben. De onderstaande opsomming geeft weer wat er precies is genoteerd per vis in elke proef.

\section{- Vis nummer}

Elke vis krijgt een identificatie nummer voor herkenning door de proeven heen

\section{- Oriëntatie}

(ten opzichte van de elektrode)
1. $=0$ graden
2. $=23$ graden
3. $=45$ graden
4. $=67$ graden
5. $=90$ graden

\section{- Mate van ingraven}
1. = boven het zand
2. = half ingegraven (ziet maar een deel van de vis)
3. = enkel de kop/ogen zijn zichtbaar
4. $=$ vis is volledig ingegraven en enkel een contour/kuiltje is zichtbaar

- Reactie tijdens blootstelling (aan puls)
1. = geen
2. = schudden / Trillen / vin beweging rondom
3. = kromtrekken - kop en staart komen los van de bodem
4. = verkramping - neus en staat raken elkaar bijna

- Reacties na blootstelling (aan puls)
1. = geen
2. = stofwolkje ademhaling (goed zichtbaar bij beelden zijkant)
3. $=$ trillen
4. = dieper / opnieuw ingraven
5. = loskomen van de grond - vis blijft op zelfde plek
6. = vluchten - verplaatsing naar andere locatie 
- Hoogste punt van de bodem
1. $=0-10 \mathrm{~cm}$
2. $=10-20 \mathrm{~cm}$
3. $=20-30 \mathrm{~cm}$
4. $=30-40 \mathrm{~cm}$
5. $=40-50 \mathrm{~cm}$
6. $=50-60 \mathrm{~cm}$
7. $=60-70 \mathrm{~cm}$ 


\section{Resultaten}

\subsection{Tong}

\subsubsection{Spanning}

Uit praktijksituaties is bekend dat puls-prikkeling met een lager voltage (V) dan 45 volt een sterke vermindering van vangst efficiëntie oplevert bij tong. Omwille van tijd is het voltage experiment met een lager voltage dan 45 volt niet uitgevoerd. Bij de uitgevoerde experimenten reageerde één $30-35 \mathrm{~cm}$ tong intenser tijdens de blootstelling aan het hogere voltage en drie $15-20 \mathrm{~cm}$ klasse reageerden intenser (Figuur 4) op de blootstelling met 60V. Na de blootstelling aan 60 volt reageerde vooral meer $15-20 \mathrm{~cm}$ tongen met een meer intense reactie door deels of volledig los te komen of vluchtgedrag te vertonen.
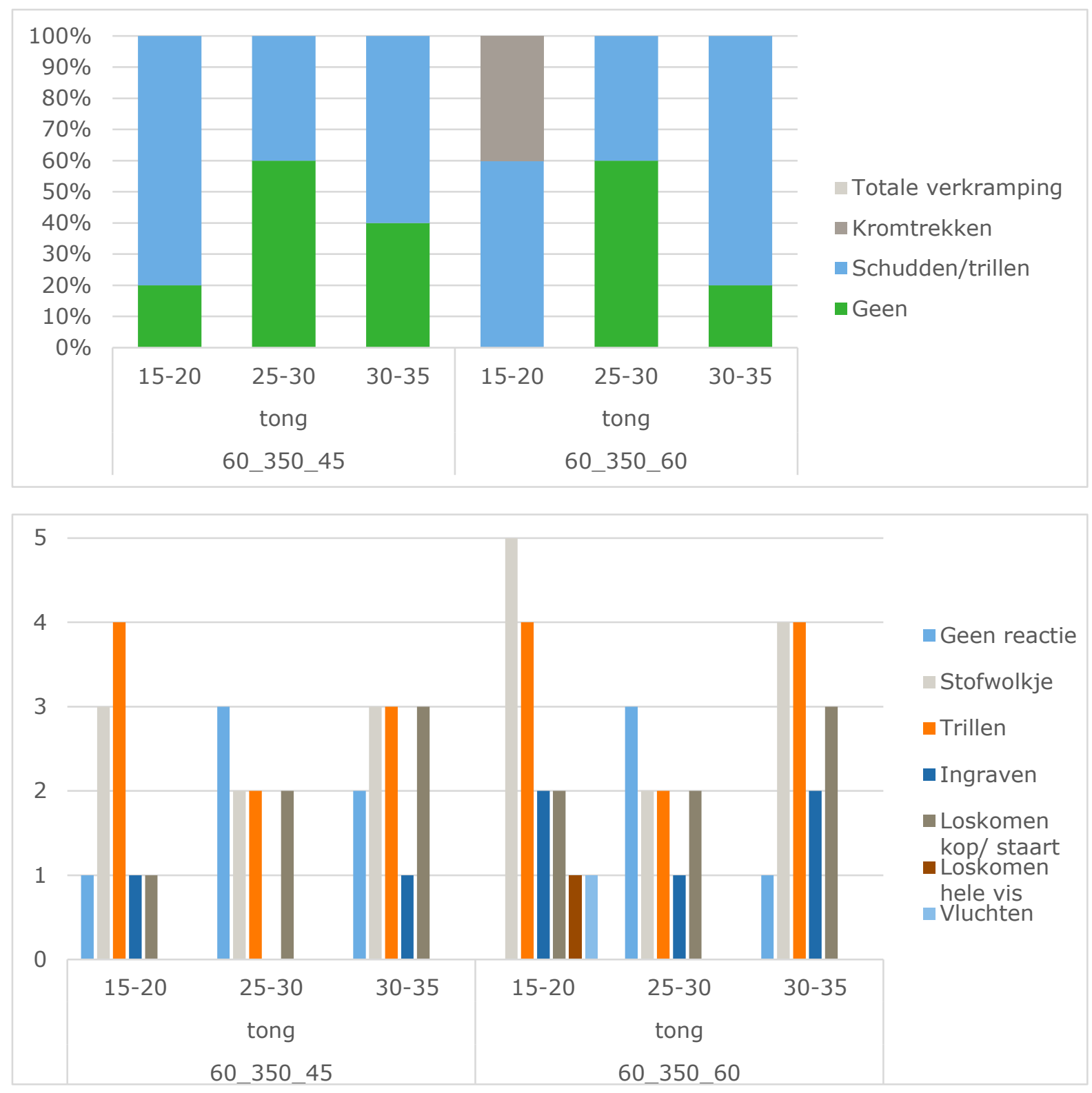

Figuur 4 Reacties van tong tijdens blootstelling (boven) wordt weergeven met het percentage van de reacties tijdens de proef op de $y$-as. De reacties na blootstelling (beneden) wordt weergegeven met het aantal dergelijke reacties op de $y$-as, één vis kan meerdere reacties tonen. Voor beide figuren staat op de $x$-as de proef en lengteklasse. V.I.n.r. staan de resultaten voor de twee instellingen met 45 en 60 volt. 


\subsubsection{Frequentie}

De reactie van tong tijdens de blootstelling wordt intenser met een hogere frequentie (Figuur 5). Bij 30 hertz toont de meerderheid van de tongen geen reactie op de puls prikkel en trekt geen enkele vis krom. Daarentegen bestaat $>60 \%$ van de reacties bij 85 hertz uit kromtrekken. Vooral tongen groter dan $25 \mathrm{~cm}$ reageren bij deze instelling intenser. $\mathrm{Er}$ is een duidelijke toename te zien in het aantal reacties na blootstelling bij hogere frequenties wat overeenkomt met de intensiteit van de reacties tijdens de blootstelling.
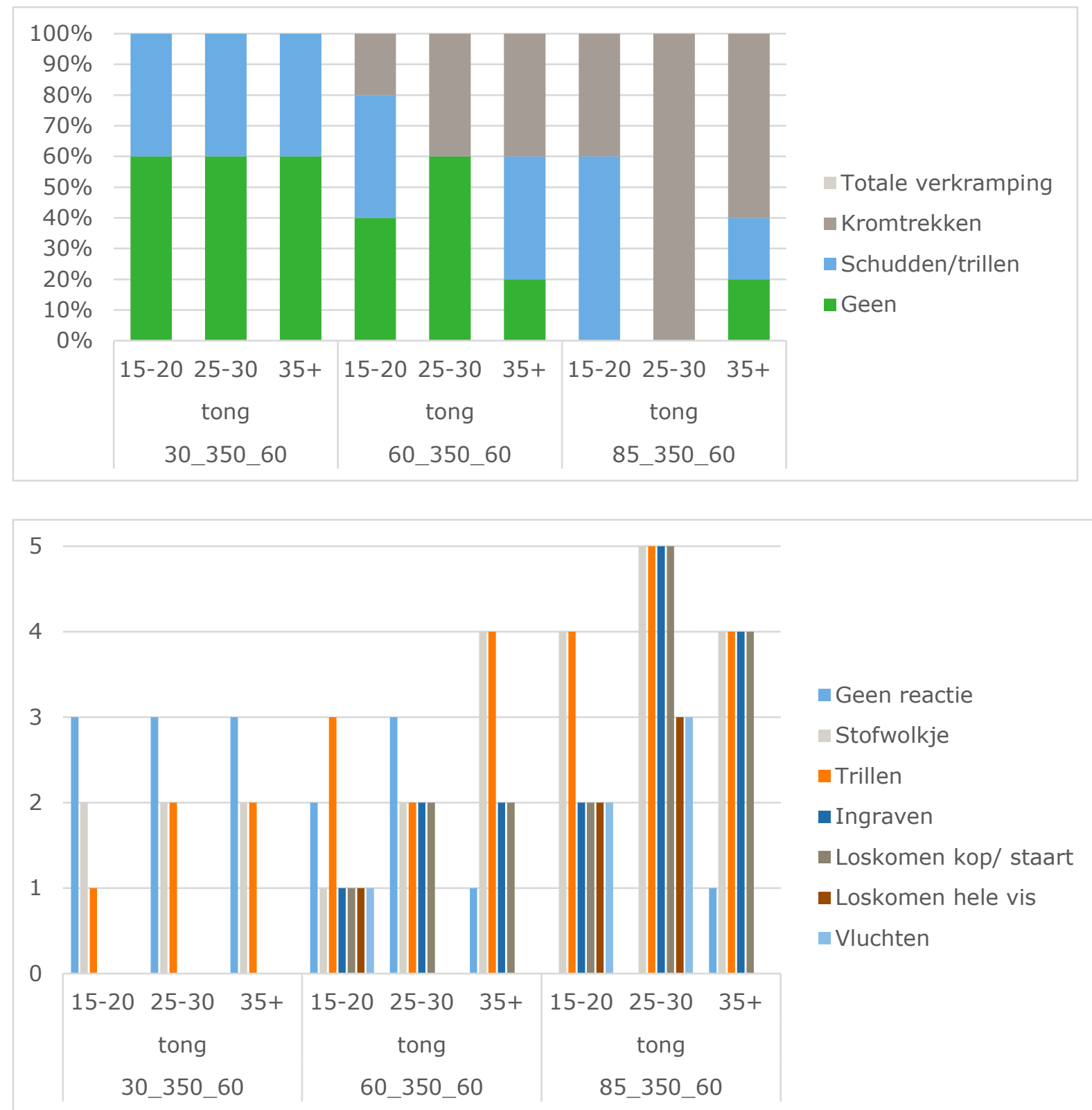

Figuur 5 Reacties van tong tijdens blootstelling (boven) wordt weergeven met het percentage van de reacties tijdens de proef op de $y$-as. De reacties na blootstelling (beneden) wordt weergegeven met het aantal dergelijke reacties op de $y$-as, één vis kan meerdere reacties tonen. Voor beide figuren staat op de $x$-as de proef en lengteklasse. V.I.n.r. staan de resultaten voor de drie instellingen met 30, 60 en 85 hertz. 


\subsubsection{Pulsduur}

Met name de grotere exemplaren reageren intenser bij een toename van de pulsduur (Figuur 6). Met elke toename in pulsduur neemt de intensiteit van de reacties van exemplaren van 25 tot $35 \mathrm{~cm}$ toe. Voor de $15-20 \mathrm{~cm}$ tongen blijft de intensiteit onveranderd over de drie proeven.

Er is geen duidelijk effect te herkennen voor de reacties na blootstelling, al lijken de grotere exemplaren vaker te reageren na blootstelling aan een langere pulsduur door meer observaties van stofwolkjes die ze uitblazen of trillen. Bij de $15-20 \mathrm{~cm}$ exemplaren is er geen trend zichtbaar.
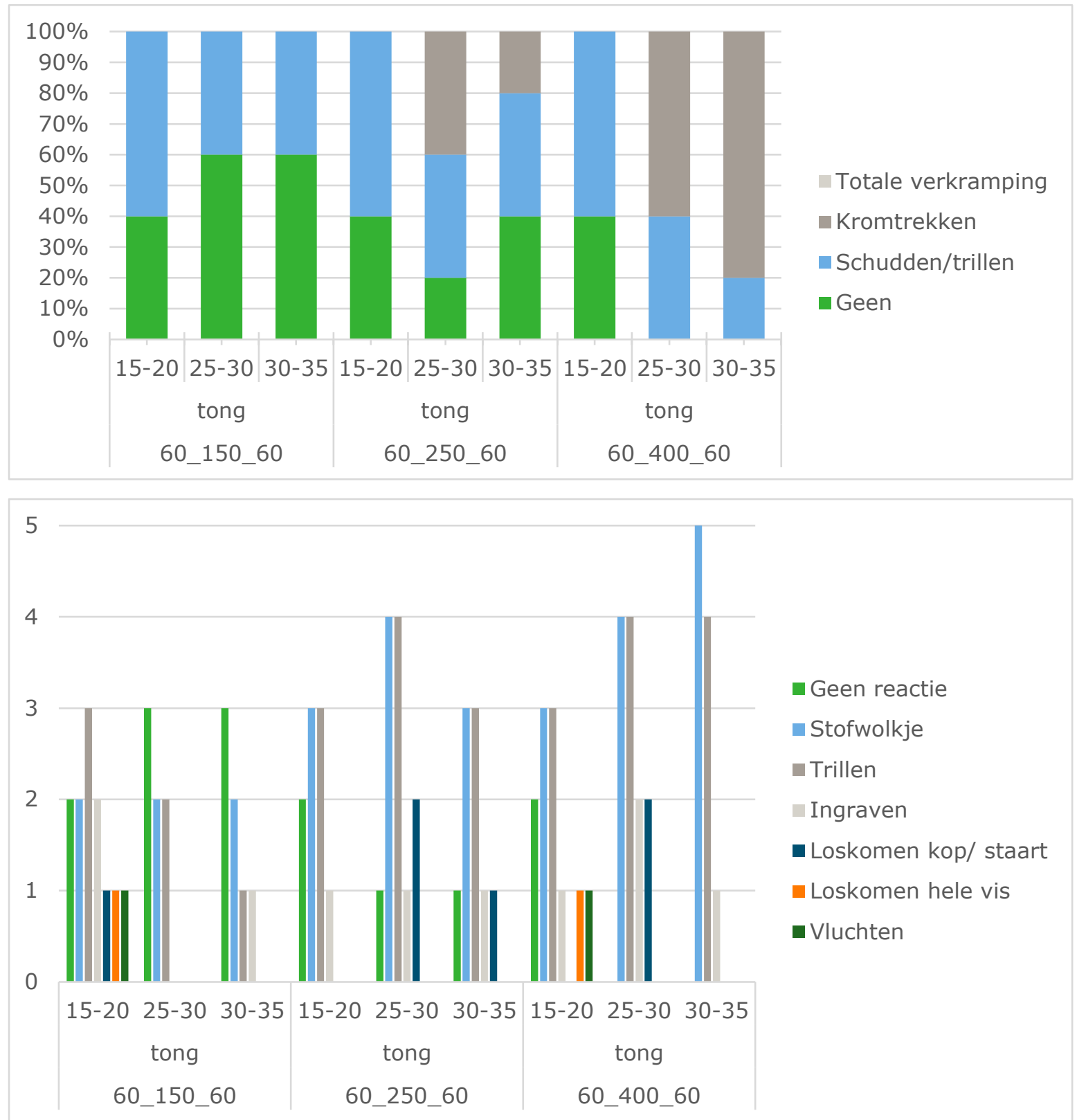

Figuur 6 Reacties van tong tijdens blootstelling (boven) wordt weergeven met het percentage van de reacties tijdens de proef op de $y$-as. De reacties na blootstelling (beneden) wordt weergegeven met het aantal dergelijke reacties op de $y$-as, één vis kan meerdere reacties tonen. Voor beide figuren staat op de $x$-as de proef en lengteklasse. V.I.n.r. staan de resultaten voor de drie instellingen met 150, 250 en 400 microseconde. 


\subsection{Schol}

\subsubsection{Spanning}

Verhogen van het voltage van 45 naar 60 volt zorgt ervoor dat schol van beide lengteklassen intenser reageren (Figuur 7). In de reacties na blootstelling zien we een minimale toename in de intensiteit bij de 25-30 cm schol doordat twee vissen bij 60 volt met kop en of staart loskomen. De vermindering in het aantal individuen dat trilt na blootstelling bij de $15-20 \mathrm{~cm}$ schol komt niet overeen met de intensere reactie tijdens de blootstelling en blijven onverklaard.
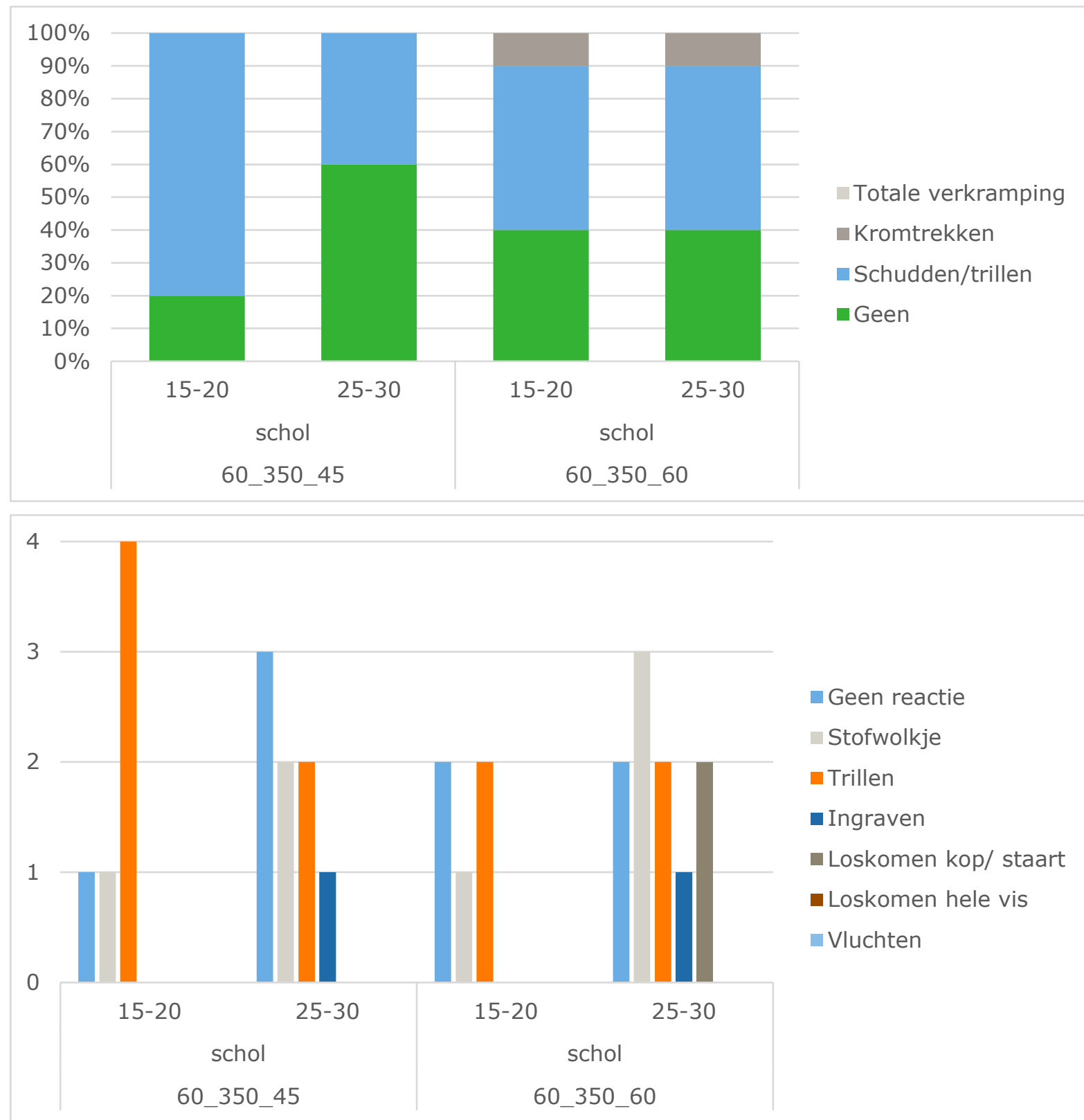

Figuur 7 Reacties van schol tijdens blootstelling (boven) wordt weergeven met het percentage van de reacties tijdens de proef op de $y$-as. De reacties na blootstelling (beneden) wordt weergegeven met het aantal dergelijke reacties op de $y$-as, één vis kan meerdere reacties tonen. Voor beide figuren staat op de $x$-as de proef en lengteklasse. V.I.n.r. staan de resultaten voor de twee instellingen met 45 en 60 volt. 


\subsubsection{Frequentie}

Het effect van een hogere frequentie is niet eenduidig voor de twee lengteklassen (Figuur 8). Bij 60 hertz trekt één schol (10\%) van 15-20 cm krom en bij 85 hertz trekken er twee 25-30 cm schollen krom. Dezelfde lengteklassen vertonen ook na de blootstelling intensere en meer reacties door met kop en staart of met het volledige lijf los te komen.
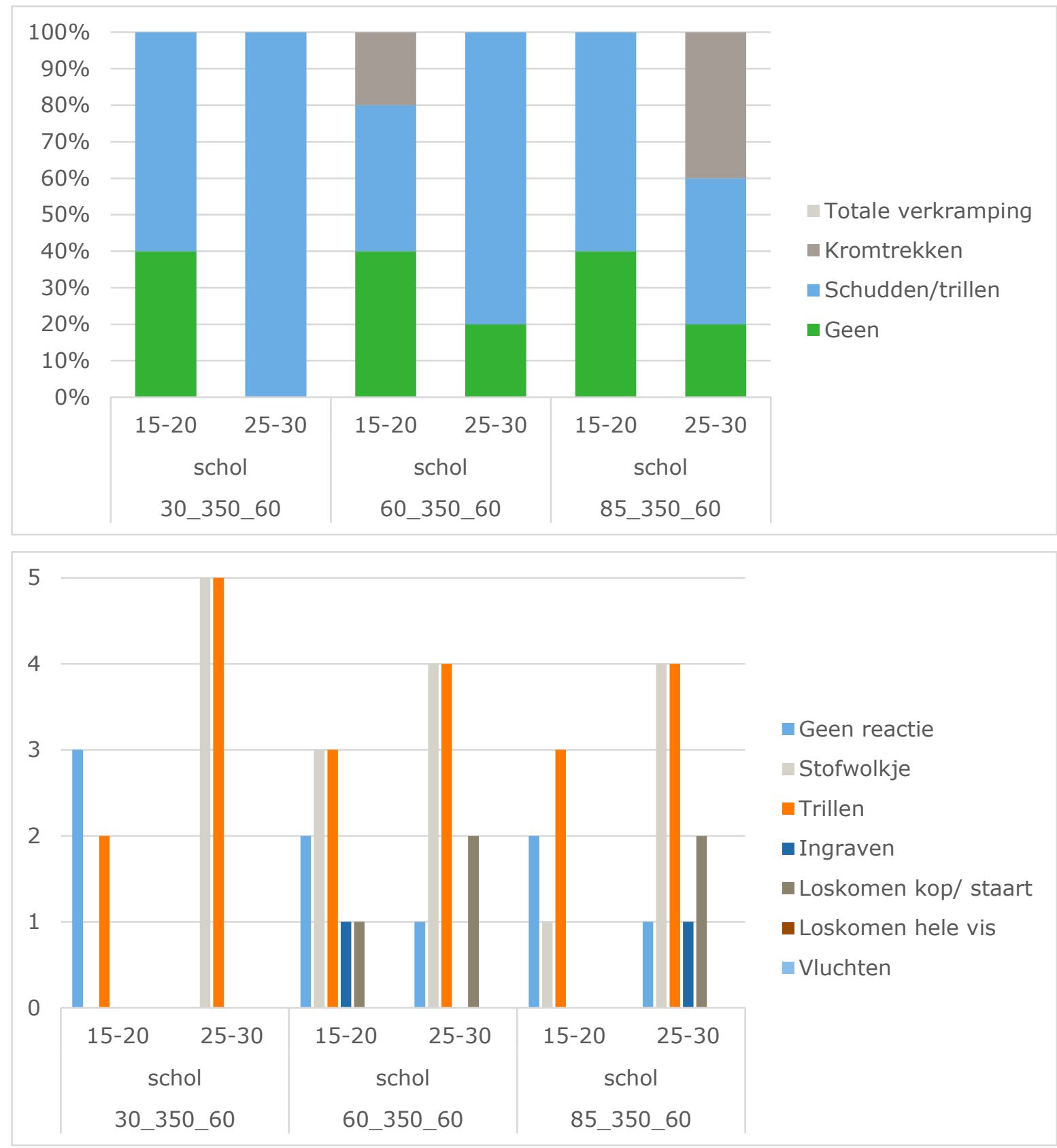

Figuur 8 Reacties van schol tijdens blootstelling (boven) wordt weergeven met het percentage van de reacties tijdens de proef op de $y$-as. De reacties na blootstelling (beneden) wordt weergegeven met het aantal dergelijke reacties op de $y$-as, één vis kan meerdere reacties tonen. Voor beide figuren staat op de $x$-as de proef en lengteklasse. V.I.n.r. staan de resultaten voor de drie instellingen met 30, 60 en 85 hertz. 


\subsubsection{Pulsduur}

Een toenemende pulsduur veroorzaakt geen duidelijk verschil in de intensiteit waarmee schol reageert (Figuur 9). Ook bij de reacties na de blootstelling is er geen duidelijk verschil op te merken, er is een minimale toename bij $15-20 \mathrm{~cm}$ schol te zien doordat er steeds meer individuen trillen, daarnaast graaft één schol zich bij $400 \mu s$ zich opnieuw in.

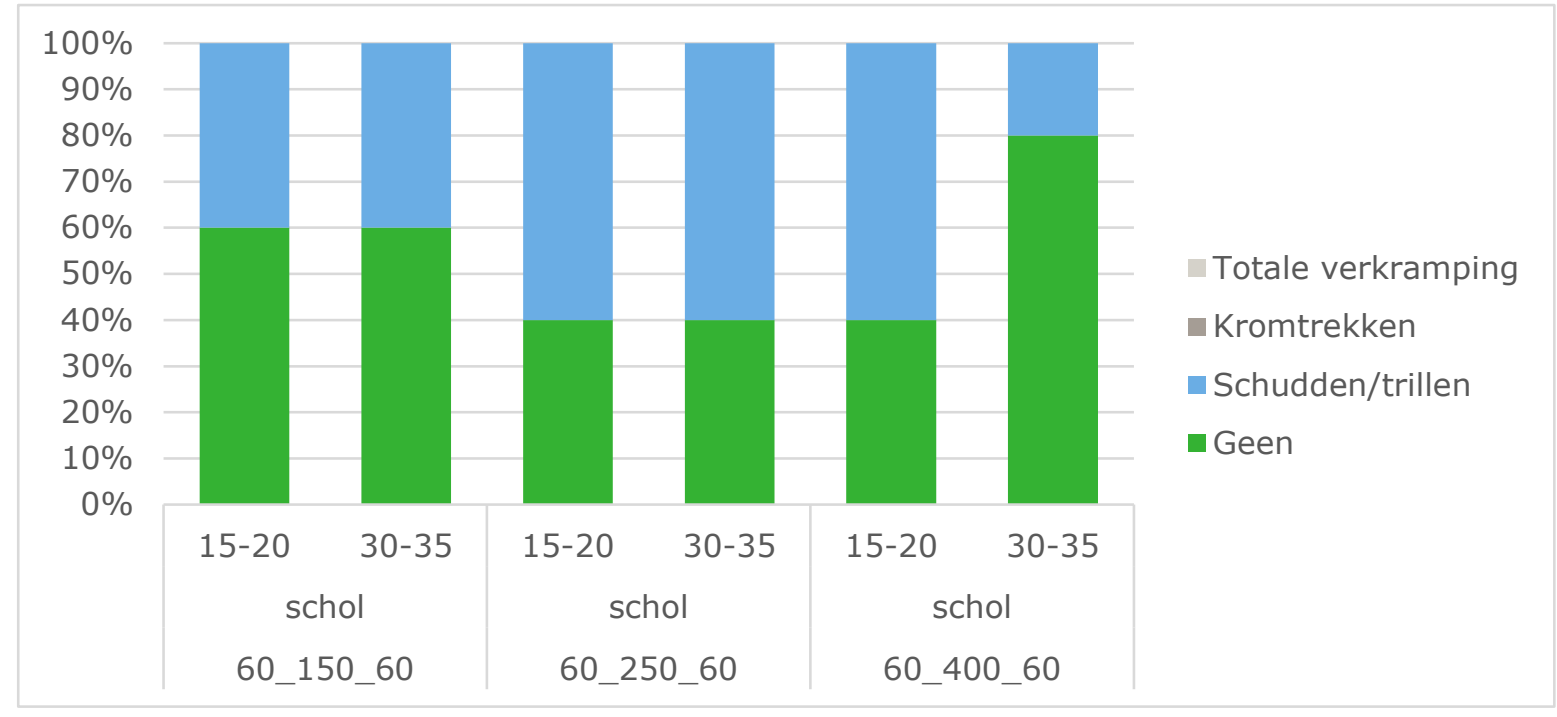

5

4

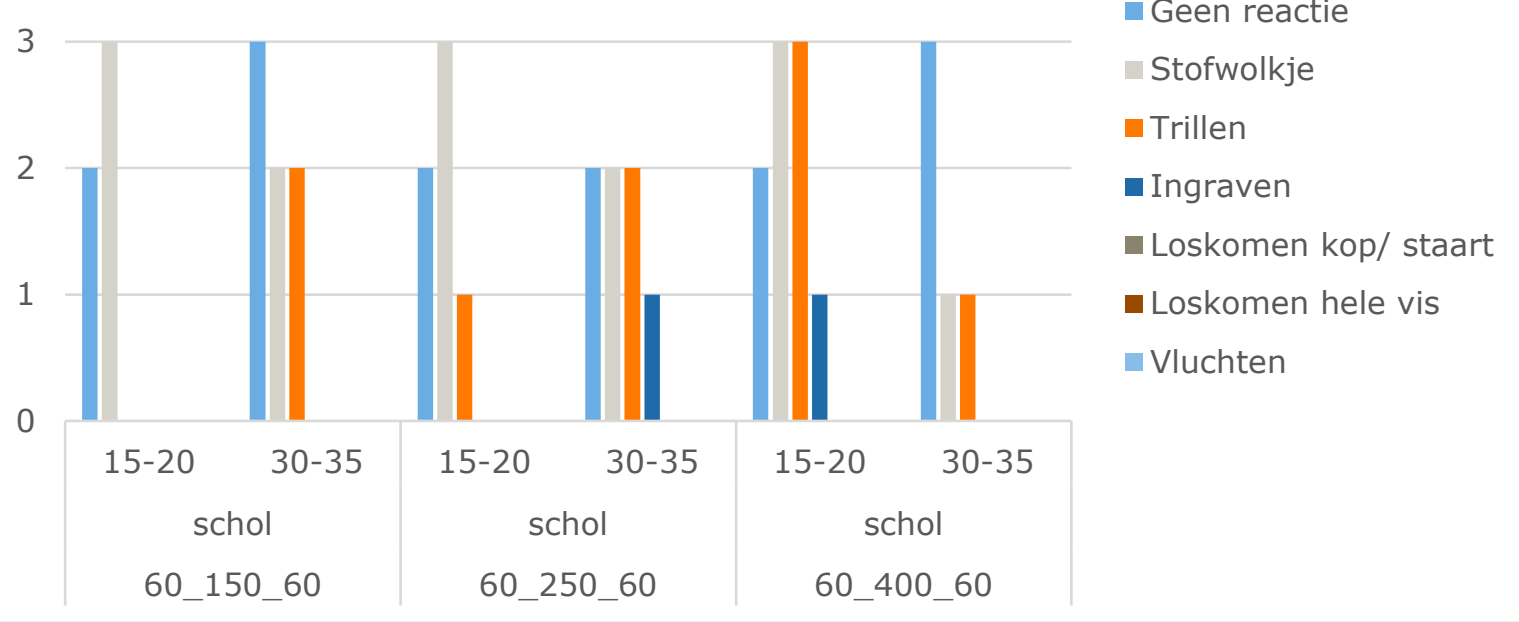

Figuur 9 Reacties van schol tijdens blootstelling (boven) wordt weergeven met het percentage van de reacties tijdens de proef op de $y$-as. De reacties na blootstelling (beneden) wordt weergegeven met het aantal dergelijke reacties op de y-as, één vis kan meerdere reacties tonen. Voor beide figuren staat op de $x$-as de proef en lengteklasse. V.I.n.r. staan de resultaten voor de drie instellingen met 150, 250 en 400 microseconde. 


\subsection{Mediërende variabelen}

\subsubsection{Conditioneringsexperiment}

Om verschil te kunnen aantonen tussen de reacties op verschillende pulsinstellingen moet bij herhaalde blootstelling aan identieke instellingen de reacties van de vissen vergelijkbaar zijn. Gewenning aan de puls-prikkeling definiëren wij als aan een duidelijke vermindering of versterking van reactie over de drie proeven met identieke instellingen. De definitie van het ontbreken van gewenning is dat de vissen bij alle drie de proeven vergelijkbare reacties vertonen.

In de reactie tijdens blootstelling aan de puls is geen duidelijke gewenning zichtbaar tussen de drie proeven (Figuur 10). Bij deze proef worden de reacties per lengteklasse met elkaar vergeleken. Voor tong zitten er kleine verschillen in de reacties tijdens blootstelling tussen verschillende proeven maar ontbreekt een duidelijke trend. Enkel kleine $(15-20 \mathrm{~cm})$ tong trilt consistent bij alle proeven. Bij schol ontbreekt het ook aan een duidelijke trend maar neigt het resultaat wel naar een iets intensere reactie na herhaalde blootstelling. De reacties na blootstelling (bv. trillen, ingraven, vluchten etc.) geven geen duidelijke trend weer (figuren in bijlage 1).
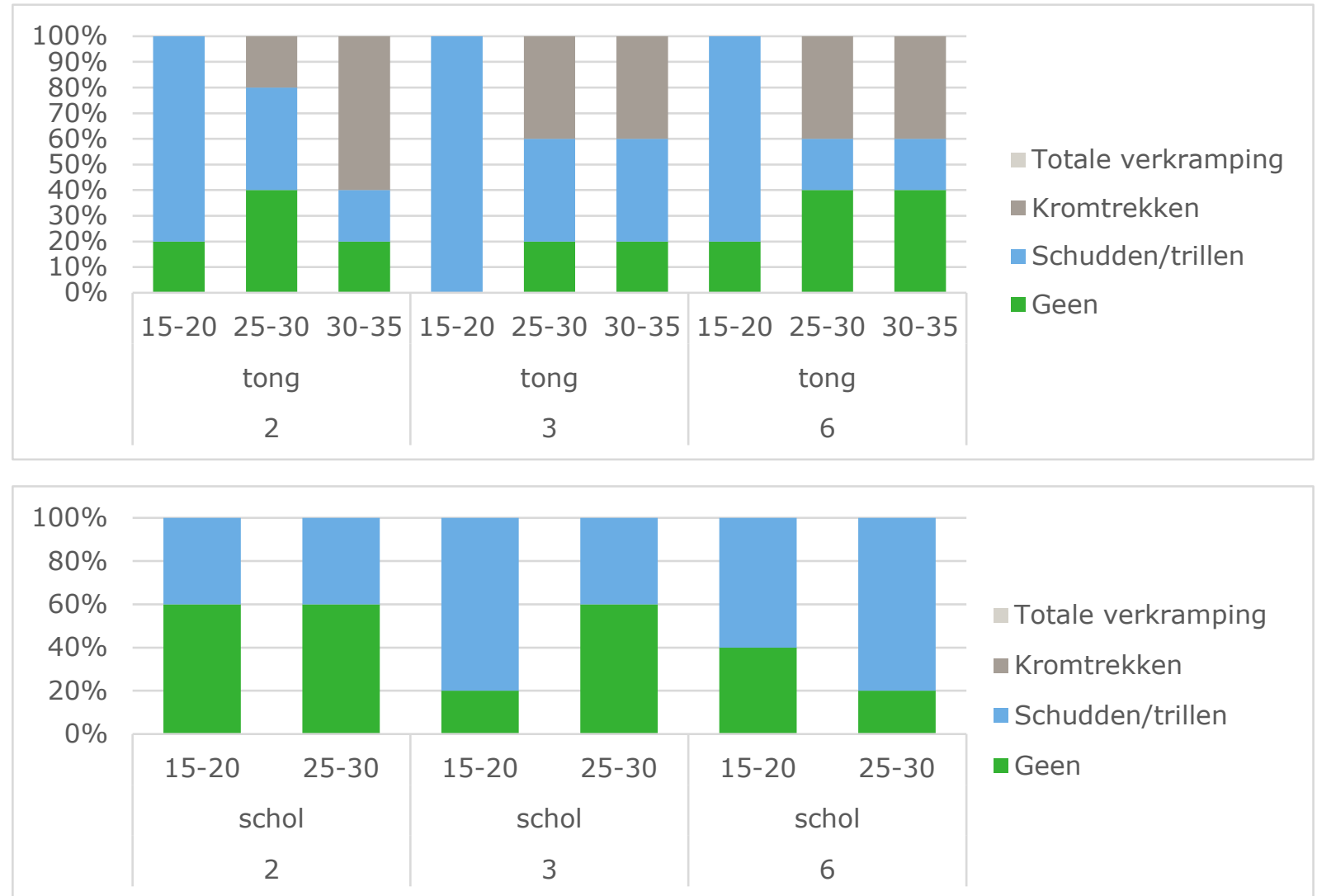

Figuur 10 Intensiteit van de reacties tijdens blootstelling aan de puls met commerciële instellingen (60 hertz, $350 \mu s, 60$ volt) voor tong (boven) en schol (onder). Op de $x$-as staat de lengteklasse, soort en het proefnummer weergegeven en op de $y$-as staat het percentage van de geregistreerde reacties. 


\subsubsection{Mate van ingraven}

Voor een goede interpretatie van de resultaten is bekeken worden of de mate van ingraven (Figuur 12) en oriëntatie (Figuur 13) gedeeltelijk verklaren hoe een vis reageert tijdens de blootstelling. Opvallend is dat het niet vaak voorkomt $(n=3 / 120)$ dat tongen zich niet ingegraven (1). Voor schol komt dit helemaal niet voor. Vooral vissen die zich volledig hebben ingegraven (4) laten geen reactie zien (Figuur 12). Tegelijkertijd is het ook moeilijker om een subtiele reactie zoals trillen waar te nemen als de vis volledig ingegraven is. Uit Figuur 12 blijkt geen duidelijke relatie te zien voor tong en schol tussen mate van ingraven en de intensiteit van de reactie tijdens blootstelling.

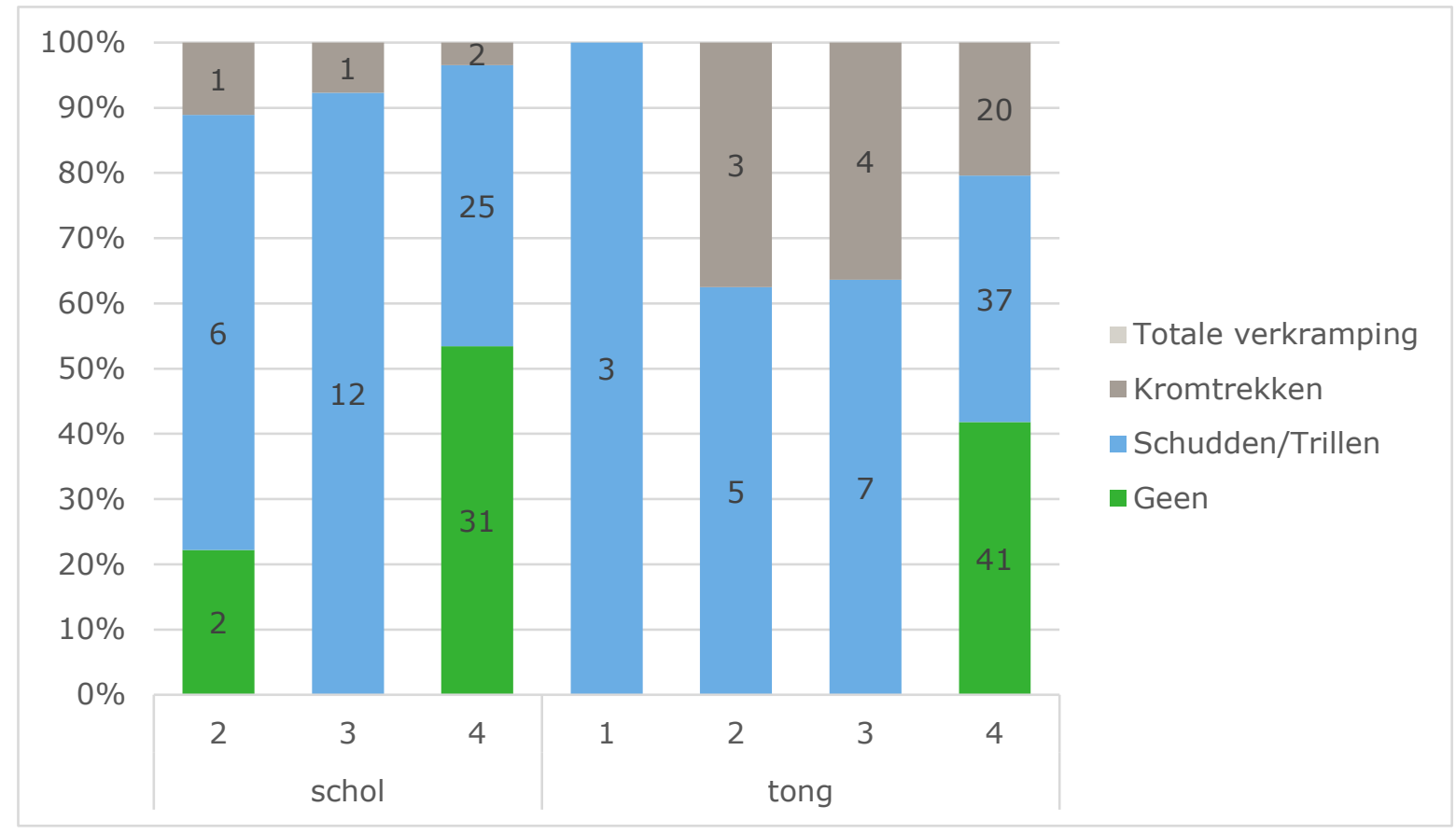

Figuur 11 Het verband tussen de mate van ingraven en de intensiteit van de reactie tijdens blootstelling wordt weergegeven. Mate van ingraven ligt tussen niet ingegraven (1) en volledig ingegraven (4) en is weergegeven op de $x$-as. De getallen weergegeven in de staafdiagrammen geven het aantal vissen weer die de betreffende reactie vertoonden. 


\subsubsection{Oriëntatie}

De oriëntatie van de vis laat geen duidelijk patroon zien over alle proeven gecombineerd met de intensiteit van de reactie tijdens de blootstelling (Figuur 12). Alle mogelijke intensiteiten van reacties komen verdeeld voor bij de verschillende oriëntaties. Bij specifiek pulsfrequentie is er wel een verband te zien tussen de reacties en oriëntatie van tong (Figuur 13). Het lijkt erop dat de reactie intenser wordt naarmate tong meer haaks op de elektrode ligt, naarmate de pulsfrequentie hoger wordt reageren tongen in elke oriëntatie intenser. Dit verband is niet zichtbaar bij pulsspanning en pulsduur. Uit de gecombineerde grafiek (Figuur 12) is duidelijk dat tong intenser reageert dan schol tijdens blootstelling aan de puls, doordat de reactie kromtrekken vaker voorkomt.

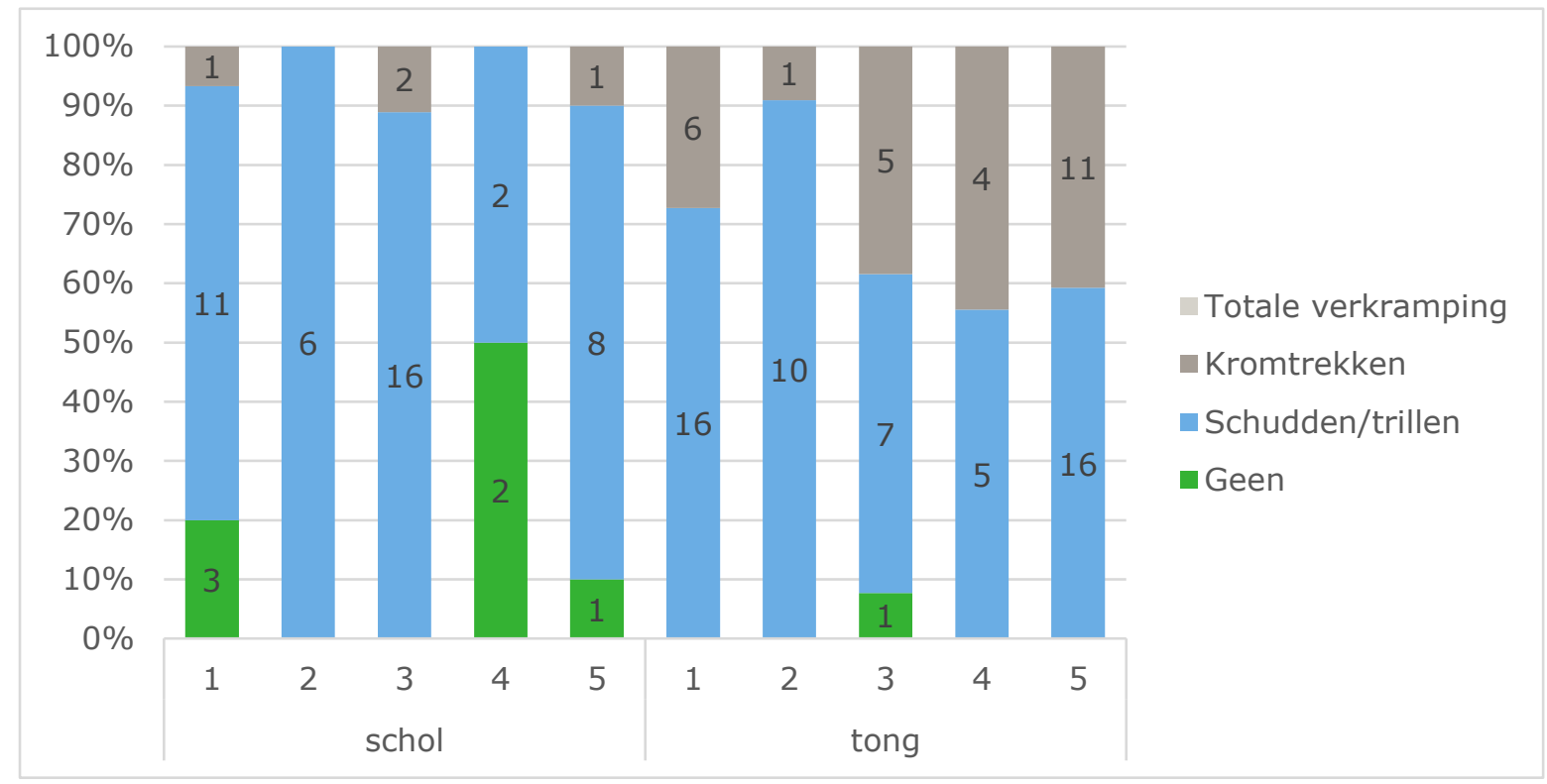

Figuur 12: Het verband tussen de oriëntatie van de vis ten opzichten van de electroden en de intensiteit van de reactie tijdens blootstelling wordt weergegeven. De oriëntatie is geclassificeerd en aangeduid met een cijfer tussen de 1 en 5. Waar bij 1 de vis evenwijdig aan de electrode ligt en 5 onder een hoek van 90 graden. De getallen weergegeven in de staafdiagrammen geven het aantal vissen weer die de betreffende reactie vertoonden.

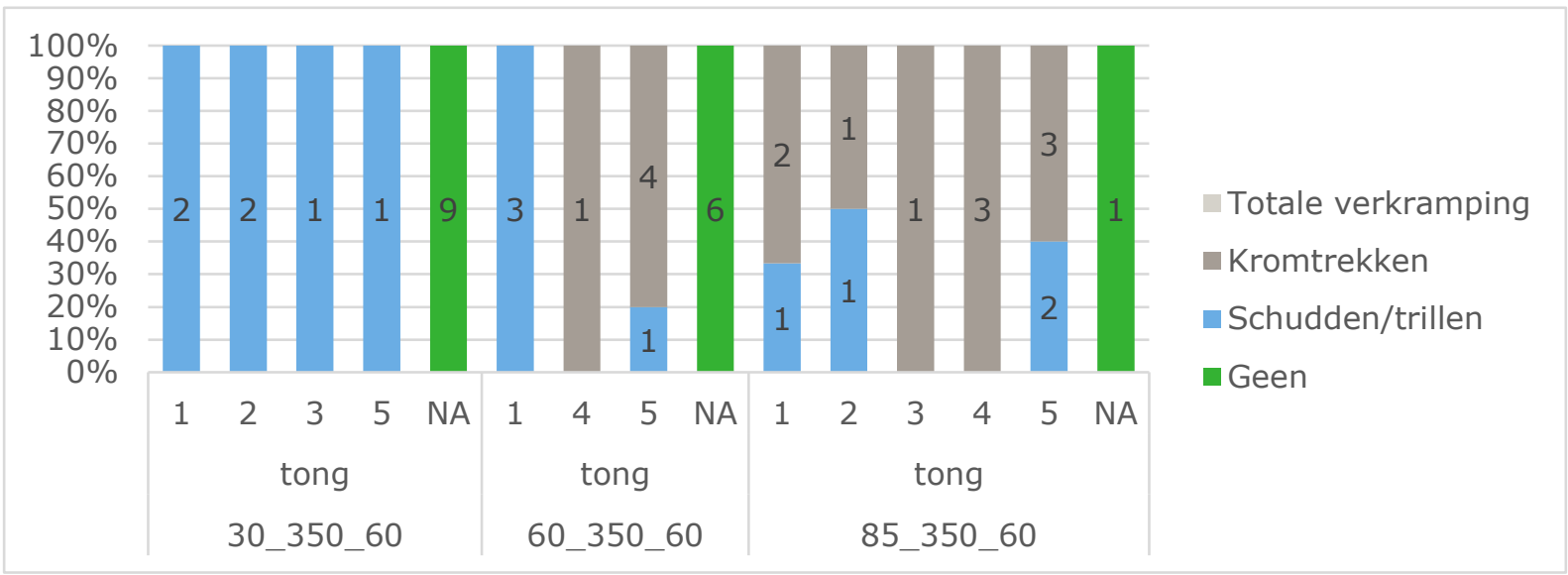

Figuur 13: Het verband tussen de oriëntatie van de vis en de intensiteit van de reactie op pulsfrequentie wordt weergegeven. De oriëntatie is geclassificeerd en aangeduid met een cijfer tussen de 1 en 5. Waar bij 1 de vis evenwijdig aan de electrode ligt en 5 onder een hoek van 90 graden. De getallen weergegeven in de staafdiagrammen geven het aantal vissen weer die de betreffende reactie vertoonden. 


\section{$5 \quad$ Discussie}

Uit de conditioneringstest blijkt dat de reacties van vissen aan de blootstelling tussen proeven variatie vertoont maar geen gewenning laat zien. De kleine verschillen tussen proeven kunnen met één enkele herhaling per instelling niet goed genoeg op waarde geschat worden. Wat in onze ogen betekent dat dit voor de interpretatie van de resultaten er bij de effecten van verschillende instellingen gekeken moet worden naar duidelijke verschillen tussen proeven.

Ook de invloed van oriëntatie op de reactie van de vissen is moeilijk te duiden, al liet de test met pulsfrequentie zien dat het verband dat er in theorie bestaat soms wel zichtbaar is maar niet duidelijk aanwezig is voor alle experimenten. Doordat een deel van de geteste instellingen het omgekeerd effect liet zien, is het mogelijk dat ondanks de optimale oriëntatie (dwars op de electrode) er geen reactie zichtbaar was. Hierdoor zijn de effecten van oriëntatie op de reactie van de vissen niet eenduidig. Het duidelijkste signaal zou te verwachten zijn tijdens de conditioneringsproef omdat deze drie keer herhaald is, maar ook hier blijft het een duidelijk effect uit. Mogelijk betekent dit dat het effect van oriëntatie en lengte op blootstelling een sterkere relatie heeft met specifieke pulsinstellingen, zoals uit het experiment met de pulsfrequentie blijkt.

De reacties van de tong op de commerciële instelling waren over het algemeen gematigd waarbij slechts een deel van de blootgestelde tongen volledig krom trok. Mogelijk heeft het ingegraven deel van het plexiglas frame van de gebruikte kooien het pulsveld beïnvloed. Het dient daarom de aanbeveling om de effecten van het plexiglas frame op het pulsveld nader te onderzoeken.

Hoe de reacties van de vissen zich laten vertalen naar de vangstkans is aan het eind van dit onderzoek nog niet duidelijk. De relatie tussen de vangkans en de puls-prikkeling is niet expliciet onderzocht in deze studie en hier ligt nog een kennisleemte. De auteurs zijn niet in staat geweest om dit verband te maken doordat de vissen in de studie niet hoog genoeg van de grond kwamen om zonder contact over de grondpees heen te gaan en omdat het niet mogelijk was om een commerciële situatie met boom, grondpees en netwerk na te bootsen. Het loskomen en verkrampen van de vissen is volgens de auteurs wel een proces waardoor de vangkans wordt vergroot. In onze ogen zouden de trillingen en waterstroming rond tuig dan kunnen zorgen voor het belangrijke zetje waarmee de vis in het net komt. 


\section{Conclusies}

Uit de resultaten van de experimenten met variërende puls instellingen blijkt dat het in gecontroleerde omstandigheden mogelijk is om gericht grotere vissen te stimuleren door middel van een puls-prikkeling. Effecten van de mediërende variabelen zijn niet eenduidig.

Bij alle experimenten is te zien dan tong intenser reageert op de puls-prikkeling dan schol. Dit is vooral duidelijk bij de pulsfrequentie en pulsduur experimenten waarbij tongen vaker dan schol de meest heftig waargenomen reactie laten zien, namelijk kromtrekken. In het experiment van pulsspanning is bij tong op te merken dat alleen de kleine tong een intensere reactie laat zien bij het hoogste voltage en is er geen verschil zichtbaar voor grotere exemplaren. Beide lengteklassen schol laten gemiddelde een meer intense reactie zien bij het hoogste voltage. De experimenten met pulsfrequentie laten voor beiden soorten een intensere reacties zien naarmate de frequentie verhoogd wordt waarbij tong de sterkste toename in intensiteit van hun reacties laat zien. Bij de hoogste frequentie reageert hier meer dan de helft van de tongen door krom te trekken. De instelling met het meest selectieve potentieel is de pulsduur. Tijdens de proeven met een oplopende pulsduur veranderen de reacties voor schol niet duidelijk terwijl grote $(>25 \mathrm{~cm}$ ) tongen een duidelijke toename in de intensiteit van hun reacties laten zien.

Hier de conclusies op hoofdlijnen:

- $\quad$ Tong reageert intenser op de puls-prikkeling dan schol.

- $\quad$ Een spanning van 45 volt ten opzichte van $60 \mathrm{~V}$ verkleint de kans om schol en kleine tong van $(15-20 \mathrm{~cm})$ te stimuleren terwijl grotere tongen $(25-35 \mathrm{~cm})$ geen verschil laten zien.

- In vergelijking met 30 hertz en 60 hertz werden er voor 85 hertz het grootste aantal reacties van tong waargenomen terwijl de reactie voor schol minimaal toeneemt bij een hogere frequentie.

- $\quad$ Een langere pulsduur vergroot de kans om grote $(25-35 \mathrm{~cm})$ tong te stimuleren maar heeft nauwelijks effect of kleine tong $(15-20 \mathrm{~cm})$ en schol.

Het verlengen van de pulsduur verhoogt de kans om grotere tong te stimuleren en heeft nauwelijks dat effect op de kleine lengteklassen. Gezien de uitkomsten van deze proeven lijkt het mogelijk om met een combinatie tussen de optimale pulsduur, frequentie en spanning de selectiviteit van het pulstuig zo te optimaliseren dan de vangst van marktwaardige vis behouden blijft, maar de vangst van kleine (ondermaatse) schol en tong beperkt wordt. Het vervolgonderzoek moet zich focussen op de optimale configuratie. Om meer zekerheid te krijgen over het werkelijke selectieve effect van deze puls instellingen en het effect (ruis) door de mediërende factoren verder uit te sluiten is het belangrijk om elke instelling in meerdere herhalingen (proeven) te testen. Dit dient te gebeuren met een combinatie van ondermaatse en marktwaardige tong en schol, met de soorten in aparte kooien conform de huidige proefopzet. 


\section{$7 \quad$ Kwaliteitsborging}

Wageningen Marine Research beschikt over een ISO 9001:2015 gecertificeerd

kwaliteitsmanagementsysteem. Dit certificaat is geldig tot 15 december 2021. De organisatie is gecertificeerd sinds 27 februari 2001. De certificering is uitgevoerd door DNV GL. 


\section{Literatuur}

D. de Haan, J. E. Fosseidengen, P. G. Fjelldal, D. Burggraaf, A. D. Rijnsdorp, 2016. Pulse trawl fishing: characteristics of the electrical stimulation and the effect on behaviour and injuries of Atlantic cod (Gadus morhua), ICES Journal of Marine Science, Volume 73, Issue 6, May/June 2016, Pages 15571569, https://doi.org/10.1093/icesjms/fsw018

EU, 2013. COM(2013) 889 final. 2013/0436 (COD). Proposal for a Regulation of the European Parliament and of the Council amending Council Regulations (EC) No 850/98, (EC) No 2187/2005, (EC) No 1967/2006, (EC) No 1098/2007, No 254/2002, (EC) No 2347/2002 and (EC) No 1224/2009 and repealing (EC) No $1434 / 98$ as regards the landing obligation. pp.

EU, 2015. Web Page: European Commission - Fisheries - CFP - Fishing rules - Landing obligation. Pp 


\section{Verantwoording}

Rapport C072/19

Projectnummer: 4313200012

Dit rapport is met grote zorgvuldigheid tot stand gekomen. De wetenschappelijke kwaliteit is intern getoetst door een collega-onderzoeker en het betreffende afdelingshoofd van Wageningen Marine Research.

Akkoord:

Nathalie Steins

Visserij onderzoeker

Handtekening:

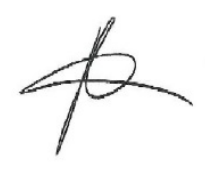

Datum:

18 juli 2019

Akkoord:

Drs. J. Asjes

Mt lid

Handtekening:

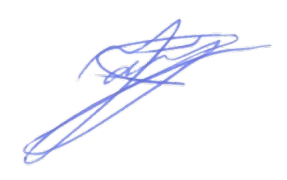

Datum:

18 juli 2019 


\section{Bijlage 1 Grafieken}

\section{Reacties na blootstelling aan commerciële puls instellingen bij het conditioneringsexperiment}
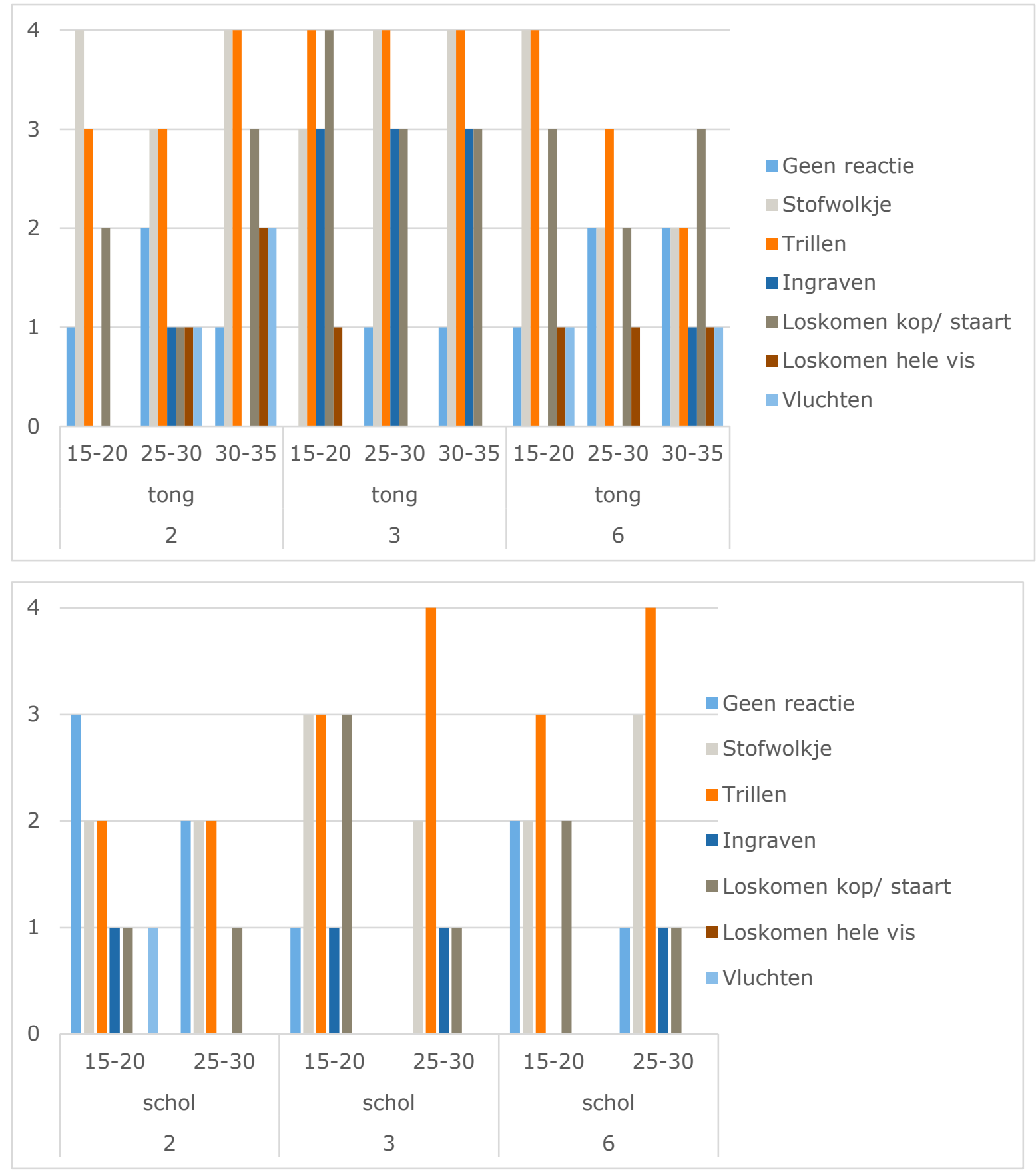


\section{Bijlage 2 Video analyse protocol}

\section{Protocol video analyse: vis reactie op puls-stimulatie}

Voordat er aan de analyse begonnen wordt, sorteer eerst alle video's waarbij voor elke proef en elke kooi de beelden van het bovenaanzicht en het zijaanzicht bij elkaar gezet worden. Dit versnelt de analyse en voorkomt verwarring van beelden.

\section{Beschrijving video analyse en data registratie}

Alle proeven worden uit twee hoeken opgenomen met camera's, de beelden kunnen dan altijd terug gekeken worden om bij voortschrijdend inzicht eventueel nieuwe waarnemingen uit dezelfde beelden te kunnen doen. Per proef worden de algemene gegevens als eerste ingevuld in het Excel bestand (figuur 1 \& bijlage). Voor elke vis per proef moet een rij met alle gegevens ingevuld worden. De eerste 7 punten kunnen gekopieerd worden voor alle vissen in die proef. Vanaf punt $8 \mathrm{t} / \mathrm{m} 11$ (Kooi nummer - individuen in kooi) moeten de gegevens per kooi apart ingevuld worden voor alle vissen.

\section{Proefnummer}

Elke losse proef krijgt een opvolgend nummer

\section{Datum}

Hierbij worden dag en maand apart ingevuld

4. Tijd

Hierbij worden minuut en uur apart ingevuld

5. Saliniteit

Meest recente meting van de dag van de proef in PSU (0-35)

6. Water temperatuur

Meest recente meting van de dag van de proef in graden Celsius

7. Puls instellingen
1. Frequentie $(\mathrm{Hz})$
2. Pulsduur (mS)
3. Voltage (V)

8. Snelheid (van de electroden door het water) In mijl per uur

9. Kooi nummer

Zie het kaartje dat vast zit met de tie-wrap

10. Soort vis

$S$ voor schol en $T$ voor tong

11. Lengteklasse vis

Lengte klasse van de vis in de kooi 20-25, 26-30...etc als de vissen niet in 1 lengteklasse passen geef de lengte range aan die er wel in. Geef toelichting bij Opmerkingen

12. Aantal individuen in de kooi

Het aantal individuen dat voor die proef in de kooi zat

\begin{tabular}{|c|c|c|c|c|c|c|c|c|c|c|c|c|c|c|c|}
\hline 4 & A & B & C & D & E & $\mathrm{F}$ & G & $\mathrm{H}$ & I & J & K & L & M & $\mathrm{N}$ & 0 \\
\hline 1 & & \multicolumn{2}{|c|}{ Datum } & \multicolumn{2}{|r|}{ Tijd } & & & \multicolumn{3}{|c|}{ Pulsinstellingen } & \multicolumn{5}{|c|}{ Proef algemeen } \\
\hline 2 & Proefnummer & Datum dag & Datum maand & Tijd uur & Tijd minuut & Saliniteit & Water temp & $\mathrm{Hz}$ & $\mathrm{ms}$ & $\mathrm{V}$ & Snelheid & Kooi & Soort & Lengteklasse & Aantal in kooi \\
\hline 3 & 1 & 15 & 5 & 10 & 15 & 32 & 18 & 60 & 350 & 58 & 4 & 1 & $T$ & $26-30$ & \\
\hline
\end{tabular}

Figuur 2.1: Een voorbeeld van de gegevens die per vis in elke proef ingevuld moet worden 
Nadat alle algemene gegevens zijn ingevoerd kunnen vis specifieke gegevens ingevoerd worden. Hiervoor moeten de beelden meerdere keren op $\mathbf{5 0 \%}$ snelheid worden afgespeeld waarbij je de spatiebalk gebruikt om het beeld stil te zetten en dus per vis de beelden rustiger te kunnen bekijken. Speel het beeld de eerste keer af van het bovenaanzicht, maak een tekening (zie bijlage voor template) van locatie en oriëntatie van de vissen voor elke proef en noteer voor elk individu punt 12-15. Bekijk de video hierna nog meerdere malen om punten 16 en 17 goed te registreren per individu. Als laatste bekijk je de video van de zijkant (met de tekening ernaast voor visidentificatie) en bevestigd wat je op de beelden van boven hebt gezien en bepaald hoe hoog de vis loskomt van de bodem. Bewaar de tekeningen en voeg deze bij als scan.

\section{Vis nummer}

Maak een tekening van het bovenaanzicht van de kooi (zie bijlage voor template) en identificeer waar welke vissen liggen voor de start van elke proef, teken de oriëntatie en nummer de vissen van links naar rechts. Voor alle drie de proeven moet de reactie van elke vis als individueel geobserveerd worden.

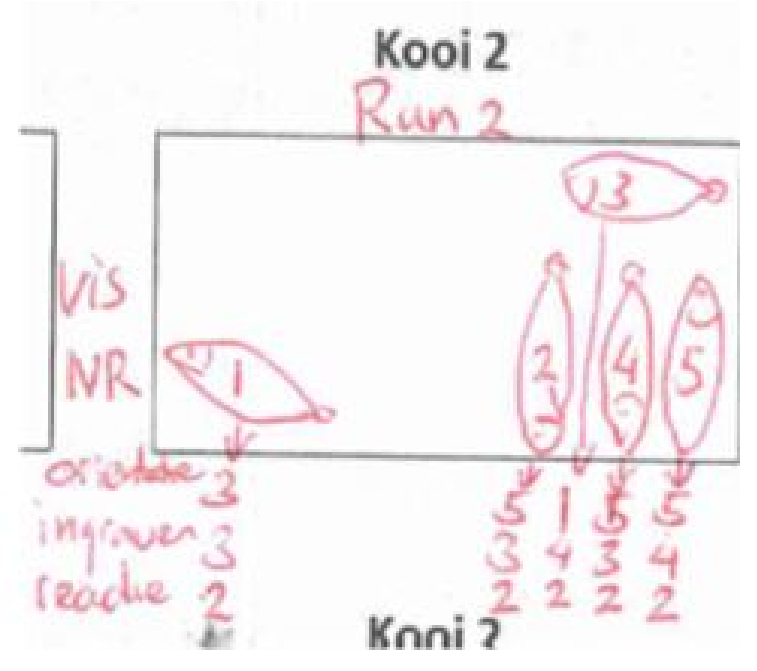

Figuur 2.2: Voorbeeld van het intekenen van de vispositie, nummering en oriëntatie

\section{Blootstelling}

Geef aan de hoeveelste blootstelling (1-3) aan de puls dit van de vis is 


\section{Oriëntatie (in de kooi)}

Geef aan wat de oriëntatie van de vis is in de kooi (1-5). De gestippelde lijn geeft de grens aan tussen de opties. Kijk voor de oriëntatie categorie naar de middellijn van de vis tussen kop en staart.
1. $=0$ graden
2. $=23$ graden
3. $=45$ graden
4. $=67$ graden
5. $=90$ graden

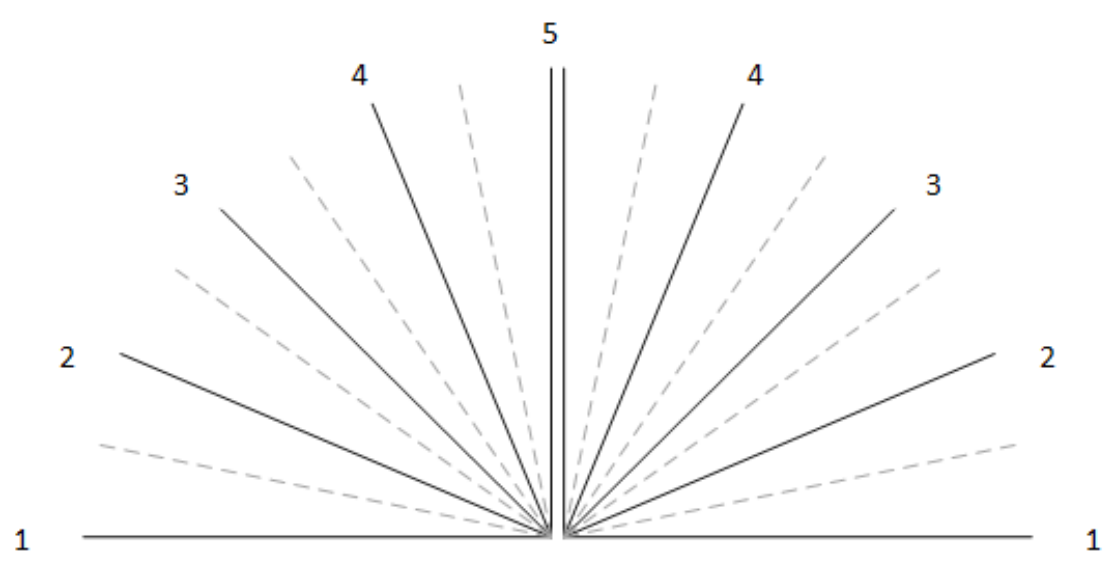

Figuur 2.3: Oriëntatie van de vis in categorieën. De middellijn (tussen staart en kop) moet binnen de hoek vallen die door de grijze stippellijn wordt aangegeven (misschien uitprinten op doorzichtig A4 papier, en de 0 lijn op het beeldscherm op de rand van de kooi leggen)

16. Ingraven (mate van)

Geef aan de mate waarin de vis zichzelf heeft ingegraven (1-4). Wordt als volgt gescoord
1. = boven het zand
2. = half ingegraven (ziet maar een deel van de vis)
3. = enkel de kop/ogen zijn zichtbaar
4. $=$ vis is volledig ingegraven en enkel een contour/kuiltje is zichtbaar
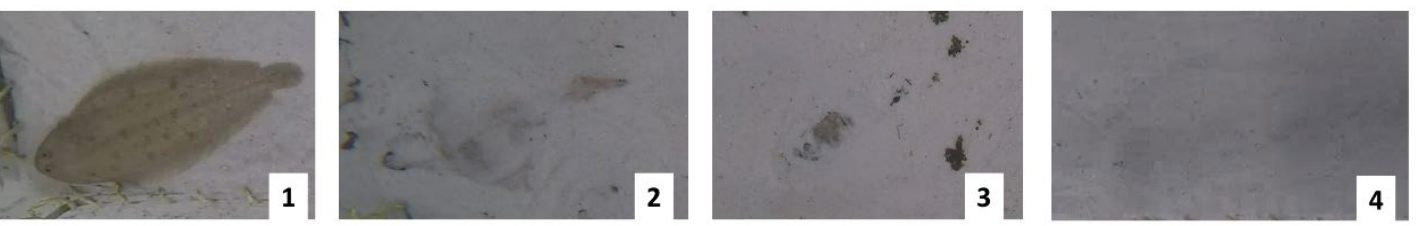

Figuur 2.4: Van links naar rechts vissen die in oplopende mate bedekt zijn 


\section{Reacties tijdens blootstelling (aan puls)}

Dit is een oplopende schaal en de meest intense reactie van de vis wordt gescoord. Bekijk de videovoorbeelden om te zien wat de classificatie is van deze reacties 6 .

1. Geen

2. Schudden / Trillen / vin beweging rondom

3. Kromtrekken - kop en staart komen los van de bodem

4. Verkramping - neus en staat elkaar bijna

\section{Reacties na blootstelling (aan puls)}

Deze reacties kunnen los van elkaar voorkomen en voor elke reactie moet aangegeven worden of deze wordt waargenomen nadat de electrode voorbij het individu is. Wanneer de reactie waargenomen wordt is vul je een $1 \mathrm{in}$, en als hij niet te zien is een 0.

1. Geen

2. Stofwolkje ademhaling (goed zichtbaar bij beelden zijkant)

3. Trillen

4. Dieper / opnieuw ingraven

5. Loskomen van de grond - vis blijft op zelfde plek

6. Vluchten - verplaatsing naar andere locatie

\section{Hoogste punt van de bodem}

Hier vul je in wat het hoogste punt van de vis is tijdens het loskomen van de grond. Gebruik daarvoor de categorieën als aangegeven in figuur 3. Indien de vis niet los is gekomen, vul 0 in.
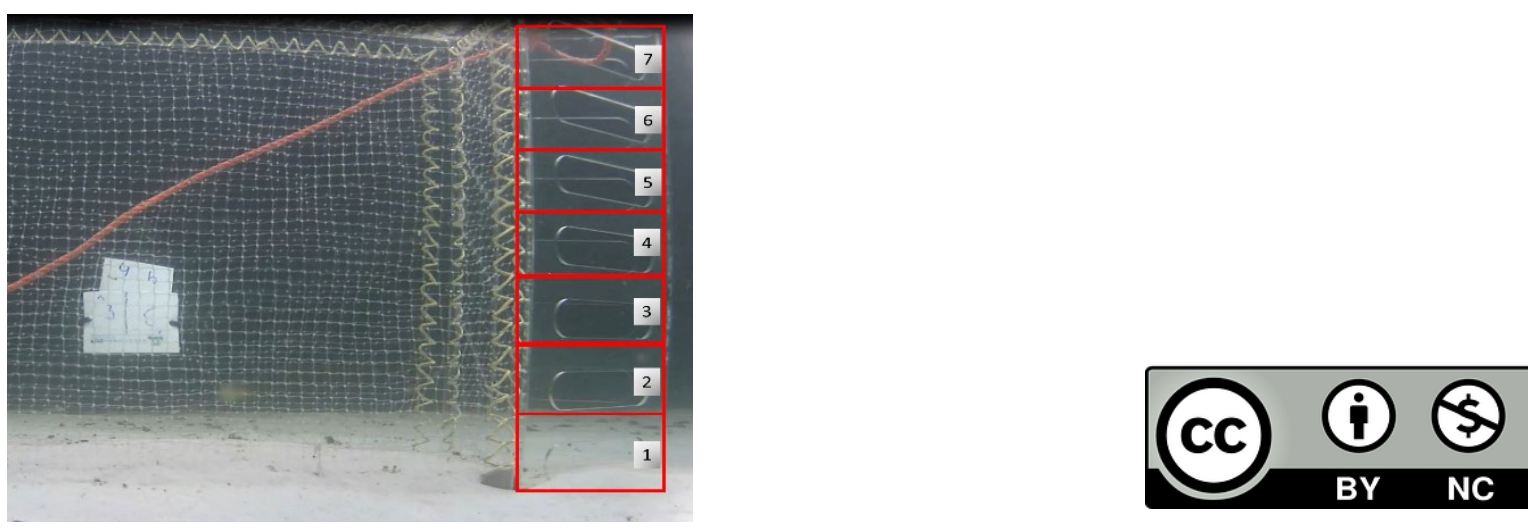

Figuur 2.5: Het hoogste punt van de vis als reactie op of na de puls moet in deze hoogte vakjes gescoord worden. 

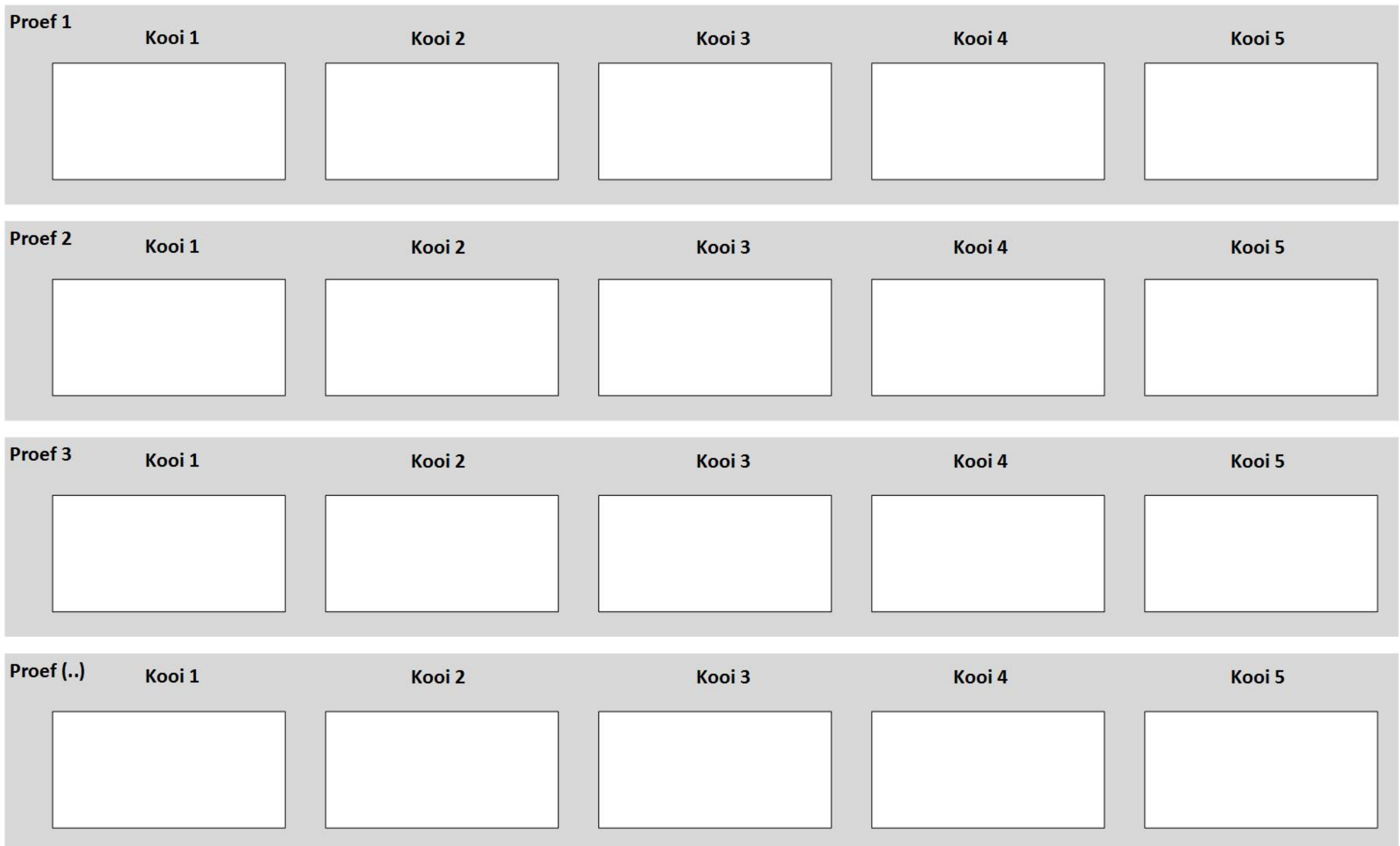


\section{Bijlage 3 Voorwaarden toestemming pulsvisserij (RvO)}

De voorwaarden waaronder met elektrische stroom kan worden gevist zijn opgenomen in artikel 31 bis, tweede lid, van de Europese Verordening Technische Maatregelen (Verordening EG nr. 850/98). Deze voorschriften, die vanaf 1 januari 2017 zullen ingaan, zijn mede tot stand gekomen na overleg met de fabrikanten van de pulsinstallaties, de sectororganisaties en de NVWA. De bijlagen I en II maken deel uit van de voorschriften.

\section{- $\quad$ Aan de toestemming zijn de volgende voorschriften verbonden:}

1. Er mag uitsluitend met een boomkor met elektrische stroom worden gevist in de ICES-zone IVc en IVb. De uiteindelijke grens is afhankelijk van de voorschriften waarop de oorspronkelijke toestemming betrekking heeft. Er mag uitsluitend met de pulskor mag worden gevist in ICES-zone IVc en IVb ten zuiden van een loxodroom die de hierna vermelde punten met elkaar verbindt, gemeten volgens het WGS84-coördinatensysteem:

- een punt op de oostkust van het Verenigd Koninkrijk op $55^{\circ} \mathrm{NB}$, dan oostwaarts tot $55^{\circ} \mathrm{NB}$ en $5^{\circ} \mathrm{OL}$, dan noordwaarts tot $56^{\circ} \mathrm{NB}$ en tenslotte op een punt op de westkust van Denemarken op $56^{\circ} \mathrm{NB}$.

2. Het Technisch Dossier aan boord (TDB), dat overeenkomstig bijlage I moet worden opgemaakt, is aan boord aanwezig. Bovendien moet voor het pulsvistuig een Technisch Dossier Fabrikanten (TDF) zijn opgemaakt overeenkomstig bijlage II.

3. Het vistuig voldoet aan de volgende voorschriften:

a. De piekspanning van de puls bedraagt ten hoogste $60 \mathrm{~V}$; gemeten tussen de aansluitingen van de elektrodes en puls modules.

b. Het maximaal uitgaande effectieve vermogen bedraagt ten hoogste $1 \mathrm{~kW}$ per meter boomlengte; gemeten tussen de aansluitingen van de elektrodes en puls modules.

c. De samenstelling van de elektroden (punt ix) van het vistuig is door de fabrikant vastgelegd in het TDF en TDB. De overige hieronder opgenomen specificaties worden opgenomen in zowel het TDF als het TDB:

i. De totale lengte van de elektrodeGemeten van het begin van het eerste geleidende deel $\mathrm{t} / \mathrm{m}$ het einde van het laatste geleidende deel, maximaal

- Minimaal 6 stuks en maximaal 12 stuks;

ii. Het aantal geleidende delen per elektrode

iii. Minimale en maximale dikte van het geleidende deel van de elektrode

- Diameter (cirkelvormig) maximaal $40 \mathrm{~mm}$ (minimale afmetingen i.v.m. begrenzing maximale onderlinge afwijkingen om te blijven voldoen aan de voorwaarden van meting onder laboratorium condities);

iv. Minimale en maximale lengte van het geleidende deel van de elektrode

- Minimaal $125 \mathrm{~mm}$ en maximaal $200 \mathrm{~mm}$;

v. Minimale en maximale lengte van de voorloop isolator ( $\mathrm{m}$ )

- Minimaal 2 meter;

vi. Aantal en lengte geïsoleerde delen per elektrode;

vii. De onderlinge afstand van de elektroden $(\mathrm{mm})$, bevestigd op de

- Tenminste $400 \mathrm{~mm}$ van hart naar hart; vleugel/boom

viii. De diameter van de staaldraad van de elektroden $(\mathrm{mm})$

- Maximaal $20 \mathrm{~mm}$.

ix. De samenstelling van de elektrode

- Opbouw en gebruikte materialen.

d. De pulsinstelling ligt tussen de 20 en 180 pulsen per seconde.

e. Het stroom voerende deel van de pulsperiode (de "duty-cycle") is niet langer dan $3,0 \%$.

f. De elektrodeparen worden niet gelijktijdig t.o.v. de naastliggende elektroden 
aangestuurd om het wekveld stabiel te houden.

g. De breedte van het totale wekveld van het tuig, gemeten als horizontale afstand tussen de twee buitenste elektroden, loodrecht op

de elektroderichting, is niet meer dan de breedte van het visnet, met een maximum van 12 meter.

4. Het vaartuig is uitgerust met een automatisch computergestuurd beheerssysteem inclusief een datalogger, dat door de fabrikant is beschreven in het TDF.

5. De data in het systeem kunnen niet gemanipuleerd worden. Behalve de handhavende autoriteiten en de fabrikant heeft niemand toegang tot het computergestuurde beheerssysteem om er wijzigingen in aan te brengen. Het systeem registreert alle hieronder genoemde gegevens gedurende tenminste de laatste 6 maanden en tenminste de laatste 100 trekken.

a. Het systeem registreert alle momenten waarop de data is uitgelezen.

b. Het systeem registreert of het vistuig aan of uit geweest is, gekoppeld aan de exacte tijd en de positie, teneinde te registreren of er in de toegestane zones gevist is.

c. Het systeem registreert de onder 3a bedoelde piekspanning en het onder $3 \mathrm{~b}$ bedoelde effectieve vermogen, waarbij per trek een diagram wordt opgesteld dat de spanning op de elektrodeparen weergeeft. Hierbij wordt minimaal 1 sample/minuut gehanteerd als resultaat van een voortschrijdend gemiddelde. Dit diagram wordt in hardcopy of digitaal aangeleverd.

d. Het voorschrift in $5 \mathrm{c}$ geldt niet indien de onder $3 a$ bedoelde piekspanning en het onder $3 \mathrm{~b}$ bedoelde effectieve vermogen automatisch gemaximeerd is op respectievelijk $60 \mathrm{~V}$ en $1 \mathrm{~kW} /$ meter. De gemaximeerde units zijn door een geaccrediteerde instelling gecertificeerd, dit betreft een type certificatie.

e. Het systeem registreert met welke pulsinstellingen er gevist is.

6. Het in onder $5 c$ genoemde diagram wordt op hun verzoek verstrekt aan de handhavende autoriteiten.

7. Voor de grondpees mogen geen kietelaars of andere visopwekkende voorzieningen worden bevestigd.

8. Op het vaartuig wordt een zwevend net gebruikt als voeding van het pulssysteem.

9. Er wordt medewerking verleend aan het monitoringsprogramma naar de effecten van de pulsvisserij dat wordt uitgevoerd in samenwerking tussen het Ministerie van Economische Zaken, de visserijsector en de onderzoeksinstituten. Deze medewerking kan mede bestaan uit het financieel bijdragen in de kosten van het programma.

10. Ten behoeve van het logboek worden de volgende vistuigcodes gebruikt:

\begin{tabular}{|l|l|}
\hline Naam vistuig & Te noteren code in logboek \\
\hline Pulskor & PUK \\
\hline Pulswing & PUL \\
\hline
\end{tabular}

11. Er wordt voldaan aan de Uitvoeringsregeling zeevisserij.

Voor de volgende onderdelen van het pulsvistuig geldt een overgangsperiode:

- Elektrodes dienen uiterlijk per 1 maart 2017 te voldoen aan de bovengenoemde vereisten. Elektrodes kunnen tussentijds vervangen worden voor nieuwe.

- Modules dienen uiterlijk per 1 maart 2018 te voldoen aan de bovengenoemde vereisten.

Indien het pulstuig niet aan de in de punten 1 tot en met 11 opgenomen voorschriften voldoet, de toestemming kan worden geschorst of kan worden ingetrokken. Bovendien kan ik op grond van artikel 53, zevende lid, van de Uitvoeringsregeling zeevisserij, de aan deze toestemming verbonden voorschriften wijzigen.

De toestemming moet tijdens het uitoefenen van de visserij aan boord van het vaartuig aanwezig zijn ten behoeve waarvan de toestemming is verleend en dient op eerste vordering aan de controle belaste ambtenaar te worden getoond. 


\section{Bijlage I technisch dossier aan boord}

Onderdeel van de controle op het pulsvistuig is het technisch dossier (TDB) aan boord. Dit TDB dient opgemaakt te worden door de fabrikant eventueel in samenwerking met de leverancier van het geleverde en geïnstalleerde pulsvistuig op uw vissersvaartuig. Naast de verklaring van de fabrikant en eventueel de leverancier dient er in het TDB tevens een verklaring van de schipper en/of eigenaar te zijn opgenomen.

Het TDB kan worden opgevraagd door een bevoegde nationale autoriteit; thans in Nederland de Nederlandse Voedsel- en Warenautoriteit (NVWA) en de Inspectie Leefomgeving en Transport (ILT). Het TDB beschrijft minimaal de volgende aspecten:

- Algemene beschrijving van de componenten bovenwaterdeel (generatoren, liersystemen, computers en datalogger). Op basis van de beschrijving moet kunnen worden beoordeeld of de installatie

- overeenkomt met de in het TDB beoordeelde uitvoering;

- Systeemkenmerken van alle componenten (naam model- en serienummers van de producten).

In het TDB dienen een aantal onderdelen/componenten nader beschreven te worden. Zie de toelichting op de technische eisen (3c) voor de specificaties.

Het is van belang dat in het TDB de elektroden worden beschreven en dat de randvoorwaarden worden vermeld door de fabrikanten van de pulsmodules. Gesteld wordt dat de bovenstaande opgegeven waarden een basis vinden in de beschikbare rapportages en daarmee een randvoorwaarde vormen.

Er is alleen ruimte om af te wijken van deze randvoorwaarden na goedkeuring van vooraf overlegd (wetenschappelijk) bewijs dat er sprake is van een vergelijkbaar niveau van:

- functionaliteit;

- effectiviteit;

- het bereiken van de doelstellingen van pulsvisserij binnen de

beleidsdoelstellingen van EZ; en

- de veiligheid.

Alleen na schriftelijke toestemming van de vergunningverlener zou, al dan niet op experimentele basis, met aangepast tuig kunnen worden gevist. Deze uitzondering beoogt ruimte te bieden aan toekomstige innovaties. Echter de vergunningverlener kan zonder opgaaf van reden de toestemming weigeren.

Het TDB kan desgevraagd aangevuld worden met nadere toelichtingen/informatie die een controle op het pulsvistuig kunnen vereenvoudigen.

\section{Verklaring schipper / eigenaar}

Bij het TDB zit een verklaring van de schipper en eventueel eigenaar dat de geleverde pulsinstallatie conform de verklaring van de fabrikant en/of leverancier is geïnstalleerd en in werking is gesteld en blijvend zal voldoen aan de voorschriften van de toestemming voor het uitoefenen van de pulsvisserij.

\section{Verklaring fabrikant / leverancier}

Bij het TDB zit een verklaring van de fabrikant eventueel met de leverancier dat de pulsinstallatie conform de daartoe vastgestelde technische eisen is geleverd.

\section{Pulsvistuig op certificaat}

In verband met de veiligheid aan boord bij het gebruik van een pulsvistuig is de Inspectie Leefomgeving en Transport (ILT) via een beleidsregel bezig om het vistuig toe te voegen aan het Vissersvaartuigenbesluit voor certificering. Dit betekent dat het vistuig onderdeel wordt van de inspectie voor het Certificaat van Deugdelijkheid en het Certificaat van Overeenstemming. Jaarlijks zal het vistuig dan worden geïnspecteerd aan de hand van de technische eisen. Deze 
Jaarlijkse inspectie ILT

Bij controle/inspectie dient een actuele versie van het TDB van het vistuig aan boord aanwezig te zijn.

Technisch dossier actueel

$\mathrm{U}$ dient het TDB actueel bij te houden en aan boord te houden.

\section{Bijlage II technisch dossier Fabrikanten}

Onderdeel van beschrijving van het pulsvistuig is het technisch dossier fabrikanten (TDF). Dit TDF dient opgemaakt te worden door de fabrikant van het geleverde en geïnstalleerde pulsvistuig op het vissersvaartuig. Dit specifieke TDF omvat de technische specificaties vanuit de fabrikant welke opgevraagd kan worden door een bevoegde nationale autoriteit; thans in Nederland de NVWA en ILT. Dit vanwege het feit dat bepaalde specificaties gevoelige bedrijfsinformatie bevat.

In het TDF dient een verklaring van de fabrikant te worden opgenomen inzake het pulsvistuig. Het TDF beschrijft minimaal de volgende aspecten:

- Alle aspecten aan de orde in het TDB en die onder de basis verantwoordelijkheid van de fabrikant vallen (waaronder de beschrijving van alle onderdelen, zoals de componenten in het systeem en de daarbij behorende detail informatie zoals van b.v. de elektroden). Het TDF bevat daarnaast aanvullend alle informatie om na te kunnen gaan of aan alle eisen wordt voldaan, maar vanuit het beschermen van bedrijfsbelangen niet in het TDB kunnen worden opgenomen. Te denken is bijvoorbeeld aan details van tekeningen, componenten in de installatie (zoals b.v. de datalogger voor registratie), ontwerp, schema's, print lay-outs en toegepaste onderdelen (zoals in de elektronica).

- Waar onderdelen van andere fabrikanten worden gebruikt, wordt gewaarborgd door middel van bewijs, dat ook deze onderdelen voldoen aan de gestelde eisen. De pulsmodule wordt gezien als kern van de installatie voor pulsvisserij. De fabrikant van de pulsmodule wordt derhalve gezien als fabrikant van het geheel. Daar waar onderdelen niet worden meegeleverd, beschrijft de fabrikant van de pulsmodule op detailniveau aan welke eisen de componenten in de installatie moeten voldoen. Het leveren van losse pulsmodules met de bestemming om te worden gebruikt voor pulsvisserij is om die reden alleen dan mogelijk als vervanging van pulsmodules die reeds in gebruik zijn gegeven.

- Voorschriften met betrekking tot de wijze en momenten waarop de veiligheidsinspecties van de verschillende onderdelen van het pulsvistuig moeten worden uitgevoerd.

Het TDF kan aangevuld worden met nadere toelichtingen/informatie die een controle op het pulsvistuig kunnen vereenvoudigen.

\section{Overig}

De fabrikant van de pulsmodule geeft binnen het kader van zijn verplichtingen invulling aan wat in het TDB is verklaard door de leverancier.

\section{Verklaring fabrikant / leverancier}

Bij het TDF zit een verklaring van de fabrikant eventueel met de leverancier dat de pulsinstallatie conform de daartoe vastgestelde technische eisen is geleverd.

Het TDF betreft een specifiek onderdeel van de beschrijving van het pulsvistuig dat uitsluitend door de genoemde bevoegde autoriteiten opgevraagd kan worden bij de desbetreffende fabrikanten. 
Dit onderdeel betreft een nadere technische toelichting op de verschillende voorschriften van de componenten/onderdelen die opgenomen dienen te worden in het TDB.

Voorschrift 3a. De piekspanning van de puls bedraagt ten hoogste 60V; Gemeten tussen de aansluitingen van de elektrodes en puls modules.

- Deze eis is om te voorkomen dat boven de maximale waarde wordt gevist. Gelet op voorschrift $5 \mathrm{c}$ dient gemeten spanning in de datalogger worden opgeslagen. Tenzij gebruik wordt gemaakt van de uitzondering als beschreven in voorschrift $5 \mathrm{~d}$. Zo weet en de inspecteur en de fabrikant waar en wanneer gemeten moet worden en of de data wordt opgeslagen.

In artikel 31 bis van de Verordening Technische maatregelen (Verordening EG nr. 850/98) wordt gesproken over een werkelijke voltage tussen de elektroden, die ten hoogste 15V bedraagt. Deze waarde is op verschillende manieren te interpreteren en is in de praktijk uitgelegd als effectieve spanning van 15 Vrms. Deze waarde sluit niet uit dat er piekspanningen ontstaan die schadelijk zijn voor het ecosysteem. Het is belangrijk dat er naast een limiet voor effectieve spanning ook een limiet voor piekspanning geldt. Deze is op basis van onderzoek vastgesteld op 60V.

Voorschrift 3c. De samenstelling van de elektroden (punt 3c ix) van het vistuig is door de fabrikant vastgelegd in het TDF en TDB. De overige hieronder opgenomen specificaties worden opgenomen in zowel het TDF als het TDB.

- Spanning wordt gemeten in drooglab. Voorschriften (en bijbehorende voorwaarden) zijn gebaseerd op wetenschappelijke studies. 'Catch Comparison of Pulse Trawls vessels and a tickler chain beam trawler' (Marlen, B. en co 2011) en 'Controle en Handhaving in de Pulsvisserij' (Van Marlen, B. \& de Haan, D. 2012).

De volgende specificaties en randvoorwaarden worden opgenomen in het TDB, in aansluiting tot datgene beschreven in de voorschriften:

- $\quad$ Elektrode piekspanning en effectieve waarde Vrms onder Lab conditie. Deze meetmethode is aan wijziging onderhevig wanneer een verbeterde meetmethode beschikbaar komt.

- Helder is dat aangetoond moet worden dat onder die voorwaarden de eis van maximaal $0,25 \mathrm{Vrms} / \mathrm{cm}$ niet wordt overschreden. In het technisch dossier moet daarom tenminste zijn opgenomen de onder laboratorium omstandigheden gemeten waarde van $10 \mathrm{Vrms}$ tussen de twee eerste geleiders van een elektrodepaar en de twee laatste geleiders van dat elektrode paar. Daartoe wordt gebruik gemaakt van een weerstand van $1 \mathrm{Ohm}$. De samenstelling van de elektrodes (zie 3c ix) moet zo zijn dattussen twee (horizontale) geleiders de eis van maximaal 0,25 Vrms/cm nergens kan worden overschreden. In het TDB wordt opgegeven met welke elektrodes de pulsmodule is beoordeeld en wordt verplicht om te gebruiken. Indien toleranties zijn aangegeven wordt bij controle uitgegaan van een worst case scenario.

- Technische tekening vistuig.

- Breedte van het wekveld (gelijk aan breedte van het net met een maximum van 12 meter)

- Kenmerken type beschrijving puls: De waarden en het bereik van de pulsstimulus met de pulsvorm, amplitude en pulsfrequenties;

- Het resultaat van de metingen van de onbelaste (zonder impedantie) elektrodespanning in "true Vrms" en de piekwaarden, in een laboratorium of aan boord van het schip uitgevoerd met apparatuur gecertificeerd door een instituut met een normering van de Raad van Accreditatie (RVA - normering). De gemeten waarden mag een maximale afwijking hebben van $2 \%$;

- Beschrijving van de wijze en momenten waarop de veiligheidsinspecties van de verschillende onderdelen van het pulsvistuig moeten worden uitgevoerd; 
- Tekening van het gehele systeem. Dit geldt zowel voor het pulsvistuig alsmede voor het geplaatste model van de bewakingsmodule.

- De samenstelling van elektrode (zie 3c ix): omvat alle gegevens over de elektroden voor zover noodzakelijk vereist. Kan bijvoorbeeld de afstand tussen de geleiders, informatie over de isolatoren, en het materiaal van de geleider omvatten.

Voorschrift $5 d$. Het voorschrift in $5 c$ geldt niet indien de onder $3 a$ bedoelde piekspanning en het onder $3 \mathrm{~b}$ effectieve vermogen automatisch gemaximeerd zijn op respectievelijk $60 \mathrm{~V}$ en $1 \mathrm{~kW} /$ meter. De gemaximeerde units zijn door een geaccrediteerde instelling gecertificeerd, dit betreft een type certificatie.

- Onder geaccrediteerde instelling wordt in deze voorschriften verstaan een organisatie welke een accreditatie heeft verkregen van de nationale accreditatieinstelling; in Nederland is dat de Raad voor Accreditatie. In die accreditatie moet zijn verklaard dat de organisatie die de accreditatie verkrijgt, voldoet aan de voorwaarden en eisen als gesteld in de norm EN 17025 "Algemene eisen voor de bekwaamheid van beproevings- en kalibratielaboratoria". In deze voorschriften is een type certificatie vereist.

Voorschrift 9. Er wordt medewerking verleend aan het monitoringsprogramma naar de effecten van de pulsvisserij dat wordt uitgevoerd in samenwerking tussen het Ministerie van Economische Zaken, de visserijsector en de onderzoeksinstituten. Deze medewerking kan mede bestaan uit het financieel bijdragen in de kosten van het programma.

- De huidige voorwaarden en artikel 14 van de basisverordening (Verordening EU nr. 1380/2013) voorziet in de mogelijkheid om in het kader van de aanlandplicht een proefproject uit te voeren om alle haalbare methoden ter voorkoming, beperking en uitbanning van ongewenste vangsten in de visserij volledig te onderzoeken. Deze toestemming om met elektrisch pulstuig te kunnen vissen maakt onderdeel uit van dit proefproject. Om de resultaten van dit proefproject te kunnen monitoren is uw deelname aan het monitoringsprogramma vereist. $U$ zult nader worden geïnformeerd over de deelname aan dit monitoringsprogramma. 
Wageningen Marine Research

T: $+31(0) 317480900$

E: marine-research@wur.nl

www.wur.nl/marine-research

Bezoekers adres:

- Haringkade 1, 1976 CP IJmuiden

- Ankerpark 271781 AG Den Helder

- Korringaweg 7, 4401 NT Yerseke
Wageningen Marine Research levert met kennis, onafhankelijk wetenschappelijk onderzoek en advies een wezenlijke bijdrage aan een duurzamer, zorgvuldiger beheer, gebruik en bescherming van de natuurlijke rijkdommen in zee-, kust- en zoetwatergebieden.
Wageningen Marine Research is onderdeel van Wageningen University \& Research. Wageningen University \& Research is het samenwerkingsverband tussen Wageningen University en Stichting Wageningen Research en heeft als missie: 'To explore the potential of nature to improve the quality of life' 